\title{
New records of non-marine, non-camaenid gastropods (Mollusca: Gastropoda) from islands off the Kimberley coast, Western Australia
}

\author{
Frank Köhler' ${ }^{1}$ Vince Kessner ${ }^{2}$ and Corey Whisson ${ }^{3}$ \\ 1 Department of Environment and Conservation of Western Australia, Science Division, PO Box 51, \\ Wanneroo, Western Australia 6946; and Australian Museum, 6 College Street, Sydney, New South \\ Wales 2010, Australia. Email: frank.koehler@austmus.gov.au \\ 2162 Haynes Road, Adelaide River, Northern Terrritory 0846, Australia. Email: vincekess@bigpond.com \\ ${ }^{3}$ Department of Aquatic Zoology, Western Australian Museum, 49 Kew Street, Welshpool, Western \\ Australia 6106, Australia. Email: corey.whisson@museum.wa.gov.au
}

\begin{abstract}
The coast of the Western Australian Kimberley boasts an archipelago that comprises several hundred large islands and thousands much smaller. While the non-marine gastropod fauna of the Kimberley mainland has been surveyed to some extent, the fauna of these islands had never been comprehensively surveyed and only anecdotal and unsystematic data on species occurrences have been available. During the Western Australian Department of Environment and Conservation's Kimberley Island Survey, 2008-2010, 22 of the largest islands were surveyed. Altogether, 17 species of terrestrial non-camaenid snails were found on these islands. This corresponds to about $75 \%$ of all terrestrial, non-camaenid gastropods known from the entire Kimberley region. In addition, four species of pulmonate freshwater snails were found to occur on one or more of four of these islands. Individual islands harbour up to 15, with an average of eight, species each. Species diversity was found to be higher in the wetter parts of the region.
\end{abstract}

KEYWORDS: Bonaparte Archipelago; Buccaneer Archipelago; Pulmonata; Cycloneritimorpha; Littorinimorpha; diversity.

\section{INTRODUCTION}

The north-western section of the Kimberley Region is a hotspot of diversity and endemism for many groups of organisms. While the flora and fauna of the mainland had been comprehensively surveyed in the late 1980s (e.g. McKenzie, Johnston and Kendrick 1991), the biota of the vast archipelago of off-shore islands has attracted relatively little attention. With the mainland biota facing various threats that relate to the impact of human activities such as the pastoral and mining industries, the introduction of alien species and anthropogenic fires, the islands along the Kimberley coast came to the forefront of conservationists' attention as they have remained relatively sheltered from the above mentioned disturbances on the mainland. Therefore, an important objective of the Kimberley Island Survey was to improve our knowledge of the islands' fauna and flora in order to understand whether the islands could function as refuges for a representative fraction of the mainland biota.

The non-marine gastropod fauna in the Kimberley was studied to some extent during the later decades of the 20th century (e.g., Merrifield et al. 1977; Solem 1991a). Because snails represent an important element of the terrestrial invertebrate biota, they are considered excellent indicators for addressing the representativeness of the islands' invertebrate fauna with respect to the mainland. Regarding the general patterns of diversity and distribution, the non-marine gastropods of the Kimberley can be roughly divided into three cohorts. Foremost and comprising the largest grouping are members of the family Camaenidae, which arguably represent the most conspicuous element of the nonmarine snail fauna and are usually characterised by their short distributional ranges (Solem 1991a). In terms of absolute species numbers, camaenids represent the largest portion of the land snail diversity in the Kimberley. About 190 species are presently known from north-western Australia (Solem 1988), belonging to 14 genera of which most are endemic to the region. Representing such a significant proportion of overall land snail diversity, the Camaenidae of the Kimberley 
islands have been treated separately (Köhler 2010a, 2010b, 2011a, 2011b). In contrast, other pulmonate and non-pulmonate land snails, which represent the second largest grouping, are predominantly represented by minute species with much larger ranges. Among these groups, only a few species are endemic to the Kimberley while most species have distributional ranges that extend beyond the borders of the region. Freshwater snails represent the third grouping of non-marine gastropods. Due to the relative scarcity of permanent freshwater bodies, the freshwater snail fauna of the Kimberley is depauperate in comparison to the diversity of terrestrial snails. The few known species usually have wider ranges through north-western Australia and, in part, further beyond.

Based on extended survey work on 22 of the larger islands along the Kimberley coast (Gibson and McKenzie, 2012), we document the non-camaenid, nonmarine gastropod fauna to facilitate an assessment of the biodiversity patterns on these islands, using snails as indicators for overall invertebrate diversity.

\section{MATERIAL AND METHODS}

\section{STUDY AREA}

The islands off the north Kimberley coast extend for a distance of approximately $800 \mathrm{~km}$ from King Sound, near Derby, in the southwest to Cambridge Gulf in the northeast, forming a number of island groups and archipelagos, including the Buccaneer and Bonaparte Archipelagos. Detailed descriptions of the survey area, including its climate, geology and vegetation are provided by Gibson and McKenzie (2012).

\section{SITE SELECTION AND SAMPLING STRATEGY}

Twenty-four of the largest islands (i.e. those with surface areas $>100$ ha) were selected as survey sites for their representativeness in terms of their geology, climatic conditions and vegetation types (Gibson and McKenzie in preparation; see below for the list of sampling sites). One or two collection sites were selected on each of these islands based on maps, satellite imagery and previous experience, with the aim of accessing as many habitat types as possible within walking distance of the base camp. Survey sites were each visited once in the wet (for one day) and dry seasons (for six days). During the dry season, aestivating snails were collected in all habitat types around the base camp by raking, digging, lifting rocks and examining tree crevices as well as by collecting leaf litter for subsequent sorting in the laboratory. Emphasis was put on densely vegetated areas such as rainforest patches and vine thickets, where snails are known to be especially abundant. In the wet seasons, snails were collected on surfaces when active at night or during rain. Further details of the survey strategy are comprehensively described by Gibson and McKenzie (2012). In addition to the 22 main survey sites on larger islands, smaller satellite islands were visited for a few hours, usually during wet season trips. At these localities snails were collected opportunistically at night or during rain.

\section{COLLECTION SITES}

Snails were collected within walking distances (usually $<1,000 \mathrm{~m}$ ) around base camps at the following localities listed in alphabetical order. For a map of the study area see Figure 1.

Main survey sites in alphabetical order (comprehensive sampling in dry and wet seasons):

Adolphus Island $\left(15.068^{\circ}-15.110^{\circ} \mathrm{S}, 128.138^{\circ}-\right.$ $\left.128.166^{\circ} \mathrm{E}\right)$

Augustus Island, north-western section (15.333 $\left.15.365^{\circ} \mathrm{S}, 124.517^{\circ}-124.530^{\circ} \mathrm{E}\right)$

Augustus Island, southern section $\left(15.382^{\circ}-15.401^{\circ} \mathrm{S}\right.$, $124.590^{\circ}-124.642^{\circ} \mathrm{E}$ )

Bigge Island, western section $\left(14.576^{\circ}-14.599^{\circ} \mathrm{S}\right.$, $125.098^{\circ}-125.109^{\circ} \mathrm{E}$ )

Bigge Island, eastern section $\left(14.586^{\circ}-14.593^{\circ} \mathrm{S}\right.$, $125.181^{\circ}-125.190^{\circ} \mathrm{E}$ )

Boongaree Island, central section $\left(15.058^{\circ}-15.077^{\circ} \mathrm{S}\right.$, $\left.125.175^{\circ}-125.189^{\circ} \mathrm{E}\right)$

Byam Martin Island $\left(15.386^{\circ} \mathrm{S}, 124.362^{\circ} \mathrm{E}\right)$

Coronation Island, northern section (14.964 ${ }^{\circ}$ $\left.14.980^{\circ} \mathrm{S}, 124.895^{\circ}-124.925^{\circ} \mathrm{E}\right)$

Coronation Island, southern section $\left(15.024^{\circ}-\right.$ $\left.15.036^{\circ} \mathrm{S}, 124.941^{\circ}-124.956^{\circ} \mathrm{E}\right)$

D'Arcy Island, northern section $\left(15.253^{\circ}-15.263^{\circ} \mathrm{S}\right.$, $\left.124.433^{\circ}-124.446^{\circ} \mathrm{E}\right)$

Hidden Island $\left(16.214^{\circ}-16.225^{\circ} \mathrm{S}, 123.448^{\circ}-\right.$ $123.459^{\circ} \mathrm{E}$ )

Katers Island, western section $\left(14.442^{\circ}-14.459^{\circ} \mathrm{S}\right.$, $\left.125.514^{\circ}-125.523^{\circ} \mathrm{E}\right)$

Kingfisher Island $\left(16.079^{\circ}-16.107^{\circ} \mathrm{S}, 124.068^{\circ}-\right.$ $\left.124.100^{\circ} \mathrm{E}\right)$

Lachlan Island $\left(16.617^{\circ}-16.623^{\circ} \mathrm{S}, 123.468^{\circ}-\right.$ $123.489^{\circ} \mathrm{E}$ )

Long Island, King Sound $\left(16.557^{\circ}-16.562^{\circ} \mathrm{S}\right.$, $123.355^{\circ}-123.364^{\circ} \mathrm{E}$ )

Middle Osborn Island, eastern section (14.311 ${ }^{\circ}$ $14.317^{\circ} \mathrm{S}, 126.021^{\circ}-126.035^{\circ} \mathrm{E}$ )

Middle Osborn Island, western section $\left(14.303^{\circ}-\right.$ $\left.14.308^{\circ} \mathrm{S}, 125.989^{\circ}-126.993^{\circ} \mathrm{E}\right)$

Nord-west Molema Island $\left(16.238^{\circ}-16.255^{\circ} \mathrm{S}\right.$, $\left.123.491^{\circ}-123.830^{\circ} \mathrm{E}\right)$

Storr Island $\left(15.944^{\circ}-15.963^{\circ} \mathrm{S}, 124.555^{\circ}-124.563^{\circ} \mathrm{E}\right)$

Sir Graham Moore Island, eastern section (13.892 $\left.13.904^{\circ} \mathrm{S}, 126.584^{\circ}-126.613^{\circ} \mathrm{E}\right)$

Sir Graham Moore Island, western section (13.868 $13.882^{\circ} \mathrm{S}, 126.511^{\circ}-126.533^{\circ} \mathrm{E}$ )

Southwest Osborn Island, eastern section $\left(14.380^{\circ} \mathrm{S}\right.$, $\left.125.934^{\circ} \mathrm{E}\right)$

Southwest Osborn Island, western section (14.364- 


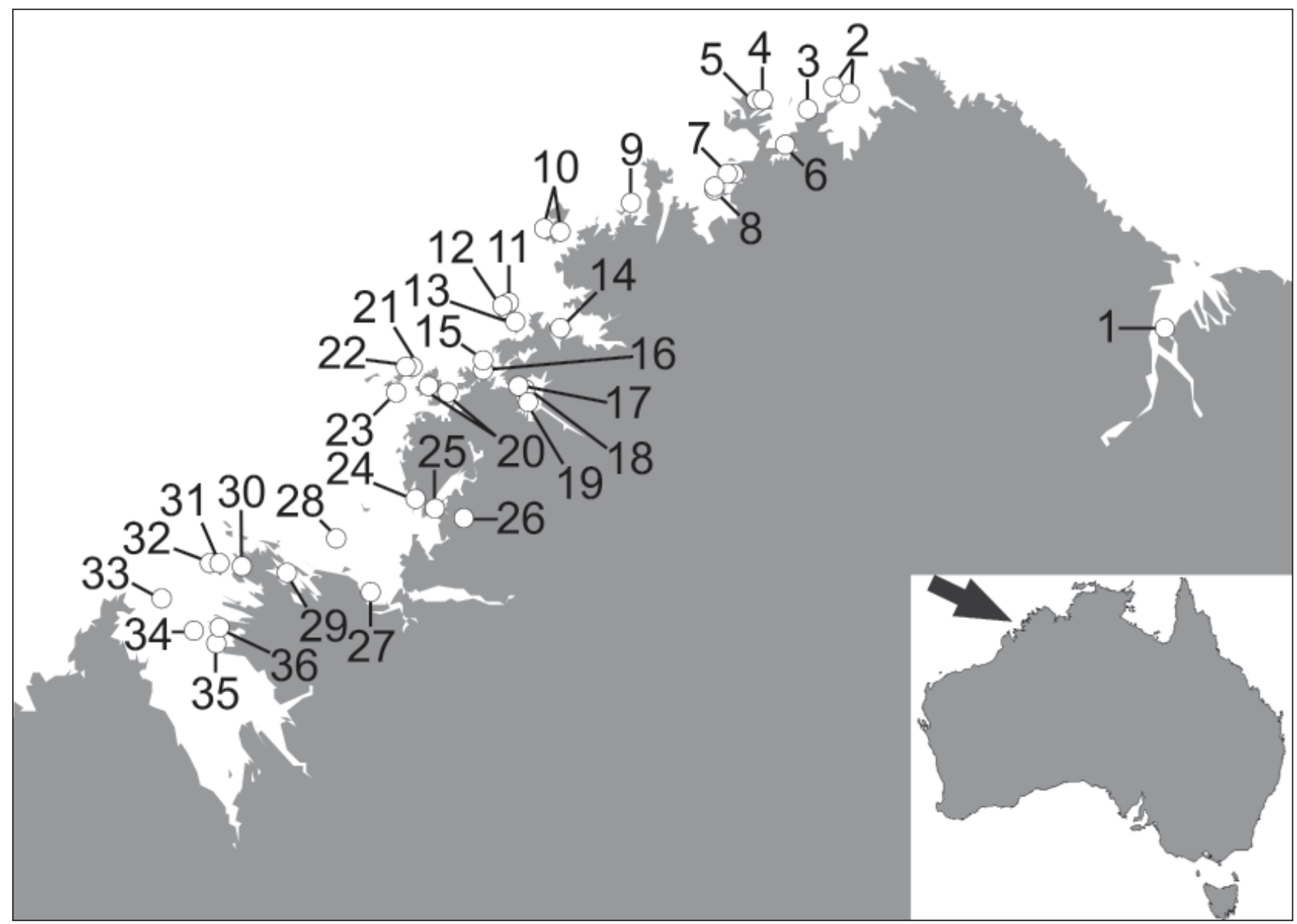

FIGURE 1 Location of collection sites: 1, Adolphus Island; 2, Graham Moore Island (E, W); 3, Mary Island; 4, Wargul Wargul Island; 5, Bougainville Peninsula; 6, Low Island; 7, Middle Osborn Island (E, W); 8, Southwest Osborn Island (E, W); 9, Katers Island; 10, Bigge Island (E, W); 11, Gale Island; 12, Coronation Island (N, S); 14, Boongaree Island; 15, Mictyis Island; 16, Uwins Island; 17, St Patrick Island; 18, St Andrews Island; 19, peninsula SE of St Patrick Island; 20, Augustus Island (N, S); 21, D'Arcy Island; 22, unnamed island, Vulcan group; 23, Byam Martin Island; 24, unnamed island in Doubtful Bay; 25, Storr Island; 26, Sale River; 27, Wulalam Island; 28, Kingfisher Island; 29, unnamed island in Talbot Bay; 30, unnamed island, Baylis Island Group; 31, Molema Island, 32, Hidden Island; 33, Sunday Island; 34, Long Island; 35, Lachlan Island; 36, peninsula in Cascade Bay.

\section{$\left.14.379^{\circ} \mathrm{S}, 125.931^{\circ}-125.945^{\circ} \mathrm{E}\right)$}

St Andrew Island $\left(15.356^{\circ}-15.360^{\circ} \mathrm{S}, 124.995^{\circ}-\right.$ $\left.125.002^{\circ} \mathrm{E}\right)$

Sunday Island $\left(16.391^{\circ}-16.432^{\circ} \mathrm{S}, 123.175^{\circ}-123.213^{\circ} \mathrm{E}\right)$

unnamed island, Doubtful Bay $\left(15.904^{\circ}-15.919^{\circ} \mathrm{S}\right.$, $\left.124.458^{\circ}-124.467^{\circ} \mathrm{E}\right)$

Uwins Island $\left(15.253^{\circ}-15.295^{\circ} \mathrm{S}, 124.785^{\circ}-124.803^{\circ} \mathrm{E}\right)$

Wulalam Island $\left(16.366^{\circ}-16.374^{\circ} \mathrm{S}, 124.229^{\circ}-\right.$ $\left.124.235^{\circ} \mathrm{E}\right)$.

Additional survey sites in alphabetical order opportunistic sampling during short visits:

Bougainville Peninsula $\left(13.933^{\circ} \mathrm{S}, 126.148^{\circ} \mathrm{E}\right)$

D'Arcy Island, central section $\left(15.281^{\circ}-15.292^{\circ} \mathrm{S}\right.$, $\left.124.398^{\circ}-124.414^{\circ} \mathrm{E}\right)$

Gale Island $\left(14.942^{\circ} \mathrm{S}, 124.924^{\circ} \mathrm{E}\right)$

Low Island $\left(14.164^{\circ} \mathrm{S}, 126.290^{\circ} \mathrm{E}\right)$

Malby Island $\left(14.950^{\circ} \mathrm{S}, 124.891^{\circ} \mathrm{E}\right)$

Mary Island $\left(13.991^{\circ}-13.984^{\circ} \mathrm{S}, 126.379^{\circ}-126.400^{\circ} \mathrm{E}\right)$
Mictyis Island $\left(15.220^{\circ} \mathrm{S}, 124.790^{\circ} \mathrm{E}\right)$

peninsula $8 \mathrm{~km}$ SE of St. Patrick Island, Saint George Basin $\left(15.434^{\circ} \mathrm{S}, 125.0064^{\circ} \mathrm{E}\right)$

peninsula $7.3 \mathrm{~km} \mathrm{SW}$ of Porter Hill, Cascade Bay $\left(16.547^{\circ} \mathrm{S}, 123.493^{\circ} \mathrm{E}\right)$

Sale River, mainland near Doubtful Bay $\left(16.028^{\circ}-\right.$ $\left.16.988^{\circ} \mathrm{S}, 124.643^{\circ}-124.766^{\circ} \mathrm{E}\right)$

St Patrick Island $\left(15.356^{\circ} \mathrm{S}, 124.965^{\circ} \mathrm{E}\right)$

unnamed island, Baylis Island Group $\left(16.216^{\circ} \mathrm{S}\right.$, $\left.123.492^{\circ} \mathrm{E}\right)$

unnamed island, Talbot Bay $\left(16.271^{\circ} \mathrm{S}, 123.826^{\circ} \mathrm{E}\right)$

unnamed island, Vulcan Islands Group $\left(15.257^{\circ} \mathrm{S}\right.$, $\left.124.406^{\circ} \mathrm{E}\right)$

Wargul Wargul Island $\left(13.932^{\circ}-13.942^{\circ} \mathrm{S}, 126.173^{\circ}-\right.$ $\left.126.181^{\circ} \mathrm{E}\right)$.

All specimens are lodged in the Western Australian Museum, Perth (WAM). 


\section{SPECIES DISTRIBUTIONS}

\section{Class Gastropoda}

\section{Clade Cycloneritimorpha}

Family Helicinidae Férussac, 1822

Pleuropoma Moellendorff, 1893

Pleuropoma walkeri (E. A. Smith, 1894)

Helicina walkeri E. A. Smith, 1894: 99.

Aphanoconia (Sphaeroconia) baudinensis Wagner, 1909 [in 1907-1911]: 217.

Pleuropoma walkeri (E. A. Smith): Solem 1988: 465466, figures 10-12; Solem 1991a: 149-150.

\section{MATERIAL EXAMINED}

Australia: Western Australia: Augustus Island, northern and southern section (WAM S37179-83, WAM S49063, WAM S49065), Bigge Island, eastern section (WAM S36000-4, WAM S36671), Boongaree Island (WAM S36005-13, WAM S36683, WAM S37683-4), Bougainville Peninsula (WAM S49373), Coronation Island, northern and southern section (WAM S37082, WAM S37190-5, WAM S37199-204, WAM S49068), D'Arcy Island (WAM S37080-1, WAM S37185-9, WAM S49064), Gale Island (WAM S49067), Katers Island (WAM S36014-7, WAM S36562-3, WAM S36576, WAM S36672-3, WAM S36713, WAM S36927), Kingfisher Island (WAM S37785-6, WAM S37934-6), Malby Island (WAM S49066), Mictyis Island (WAM S49069), Middle Osborn Island, eastern and western section (WAM S36018-31, WAM S36564, WAM S36674-5, WAM S36684, WAM S36924-6), Sale River, Doubtful Bay (WAM S49383), Southwest Osborn Island, eastern and western section (WAM S36032-9, WAM S36473, WAM S36676, WAM S36896, WAM S36928-9), Storr Island (WAM S37929-33), St Andrew Island (WAM S37184), Uwins Island (WAM S37196-8), Wargul Wargul Island (WAM S49371-2).

\section{REMARKS}

This species was transferred to the genus Pleuropoma by Iredale (1939), and this was followed by Solem (1988). The name Aphanoconia baudinensis Wagner, 1909 was introduced as an unnecessary replacement name for Helicina walkeri and therefore is permanently invalid (Fulton 1915). Solem (1988) provided comparative remarks on shell and operculum morphology and basic data on ecology and distribution

\section{DISTRIBUTION AND ECOLOGY}

An inhabitant of vine thickets and rainforest patches with a patchy distribution in the Kimberley and adjacent regions of the Northern Territory (Solem 1991a) (Figure 2).

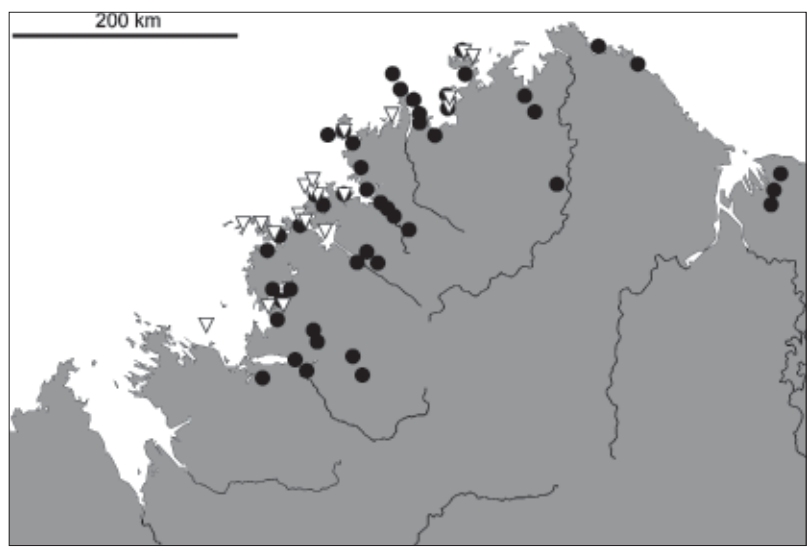

FIGURE 2 Distribution of Pleuropoma walkeri in the Kimberley: - previous records (Solem 1991a), $\nabla$ new records from this survey.

\section{Clade Littorinimorpha}

\section{Family Assimineidae H. Adams and A. Adams, 1856}

\section{Assimineid new genus, new species}

\section{MATERIAL EXAMINED}

Australia: Western Australia: Middle Osborn Island, western section (WAM S36077-81, WAM S36881-2, WAM S36930, WAM S36957, WAM S36968).

\section{REMARKS}

The studied material is considered to represent an undescribed terrestrial assimineid species, thought to belong to a new genus.

\section{DISTRIBUTION AND ECOLOGY}

The species was found only on Middle Osborn Island in leaf litter in vine thickets at the base of a north-west facing cliff.

\section{Clade Hygrophila}

\section{Family Lymnaeidae Rafinesque, 1815}

\section{Austropeplea Cotton, 1942}

\section{Austropeplea lessoni (Deshayes, 1830)}

Limnaea lessoni Deshayes, 1830: pl. 16, figures 1-2.

Austropeplea lessoni (Deshayes): Hubendick 1951: 178; Puslednik et al. 2009: 643-659.

\section{MATERIAL EXAMINED}

Australia: Western Australia: Bigge Island, eastern section (WAM S36722, WAM S36935), Coronation Island, northern section (WAM S37084, WAM S37431-3), Southwest Osborn Island, western section (WAM S36723), Wargul Wargul Island (WAM S49393, WAM S49395). 


\section{REMARKS}

According to the currently accepted taxonomy, two species of Austropeplea are recognised from Australian freshwater habitats, A. lessoni and A. tomentosa (ABRS 2009; Puslednik et al., 2009). As currently delimited, $A$. lessoni has an extended synonymy (ABRS 2009), which is not repeated here. Puslednik et al. (2009) studied morphological and molecular differentiation within Austropeplea across the entire Australian continent concluding that these data reveal inconsistent results. A molecular phylogeny based on a combination of mitochondrial (16S rRNA) and nuclear (ITS2) sequences revealed only two well differentiated clusters, which are consistent with the currently recognised species A. tomentosa and A. lessoni. By contrast, a combined analysis of molecular and morphological characters resulted in the identification of four lineages within A. tomentosa and two lineages within A. lessoni along geographical gradients. While this study confirmed the existence of a separate Western Australian morphotype within A. lessoni, we here follow the current taxonomic treatment where all populations from central and northern Australia are subsumed under the name $A$. lessoni.

\section{DISTRIBUTION AND ECOLOGY}

The species is widely distributed throughout Australia, including large areas of northern and central Australia and the Murray Darling Basin, where it lives in lentic and lotic waters feeding on detritus (ABRS 2009).

\section{Family Planorbidae Rafinesque, 1815}

\section{Gyraulus Charpentier, 1837}

\section{Gyraulus hesperus (Iredale, 1943)}

Glyptanisus hesperus Iredale, 1943: 226.

Gyraulus hesperus (Iredale): Smith 1992: 269; Brown 2001: 58-66, figures 15A-F, 28C, 31B-C.

\section{MATERIAL EXAMINED}

Australia: Western Australia: Coronation Island, northern section (WAM S37436-9), Wargul Wargul Island (WAM S49394).

\section{REMARKS}

The species-level taxonomy of Australian Gyraulus species has recently been revised by Brown (2001) based on anatomical characters. Accordingly, in the Kimberley region two species, G. hesperus (Iredale, 1943) and G. essingtonensis (Smith, 1883), are recognised, differing subtly in their shell morphology (concavity of the left side of the shell, coiling, and depression of whorls). Both species are widespread across northern Queensland, the Northern Territory and northern Western Australia. The present samples are identified as $G$. hesperus based on their relatively keeled periphery.

\section{DISTRIBUTION AND ECOLOGY}

This species lives in various kinds of more permanent freshwater habitats. The type locality of this species is the Fitzroy River, Kimberley. It has been recorded from numerous localities in Western Australia (Kimberley, Pilbara), the Northern Territory (Katherine District) and Queensland (north-western part) (Brown 2001).

\section{Isidorella Tate, 1896}

\section{Isidorella egregia (Preston, 1906)}

Limnaea (Bulinus) egregia Preston, 1906: 36.

\section{MATERIAL EXAMINED}

Australia: Western Australia: Katers Island (WAM S36883).

\section{REMARKS}

In his revision of the buliniform planorbid gastropods of Australia, Walker (1988) demonstrated that Isidorella is a distinct and endemic Australian genus characterised by key features of the copulatory organs (i.e. absence of accessory bursa or flagellum and pendant penis with two folded processes). Smith (1992) listed only a single taxon, I. newcombi (A. Adams and Angas, 1864), as a valid species within this genus. The present species is currently assigned to Glyptophysa in the Australian Faunal Directory (ABRS 2009). However, this taxonomic placement does not reflect the results of a recent taxonomic revision and is therefore considered to be tentative. Dissection revealed anatomical features typical of Isidorella (Winston Ponder, personal communication), which is reflected in the taxonomic treatment given here. This species should not be confused with Glyptopupoides egregia (Hedley and Musson, 1892), which is a pupillid species.

\section{DISTRIBUTION AND ECOLOGY}

Only one population was found in a small freshwater pool. In the collection of the Australian Museum there is a possibly conspecific specimen (AM C417292 from the Burrup Peninsula, near Dampier, WA). This might indicate a wider, albeit sparse distribution of this species in north-western Western Australia.

\section{Bayardella Burch, 1977}

Bayardella johni Burch, 1977

Plesiophysa (Bayardella) johni Burch, 1977: 79-80.

Bayardella johni (Burch): Walker 1988: 80.

\section{MATERIAL EXAMINED}

Australia: Western Australia: Bigge Island, eastern section (WAM S367250), Coronation Island, northern 
section (WAM S37434-5), Southwest Osborn Island, western section (WAM S36726), Wargul Wargul Island (WAM S49352).

\section{REMARKS}

The taxon Bayardella was elevated to the rank of genus by Walker (1988) based on a detailed examination of its anatomy.

\section{DISTRIBUTION AND ECOLOGY}

The species has been recorded from lotic freshwater habitats throughout the Kimberley as well as from the adjacent Katherine district, Northern Territory (Walker 1988).

\section{Clade Stylommatophora}

Family Pupillidae Turton, 1831

Pupisoma Stoliczka, 1873

\section{Pupisoma orcula (Benson, 1850)}

Helix orcula Benson, 1850: 251.

Pupisoma orcula (Benson): Pilsbry 1920 [in 1920-1921]: 31-34, pl. 2, figures 1-5; van Benthem Jutting 1952: 363, fig. 40; 1964: 6; Solem 1988: 472-473, figures 18, 21-23; Solem 1991a: 152; Solem 1991b: 250.

\section{MATERIAL EXAMINED}

Australia: Western Australia: Bigge Island, eastern section (WAM S 36335-6), Boongaree Island (WAM S36337-40), Bougainville Peninsula (WAM S49362), Coronation Island, northern and southern section (WAM S37455-68), D’Arcy Island (WAM S37451-2), Katers Island (WAM S36341-3, WAM S36919), Middle Osborn Island, eastern and western section (WAM S36344-6, WAM S36918), Southwest Osborn Island (WAM S 36347-50), St Andrew Island (WAM S37453), Uwins Island (WAM S37469), Wulalam Island (WAM S37905).

\section{REMARKS}

This taxon was transferred to Pupisoma by Pilsbry (1920), and this placement was followed by subsequent authors. Solem (1988) provided comparative remarks on its shell and operculum morphology and basic data on its ecology and distribution.

\section{DISTRIBUTION AND ECOLOGY}

Apparently with a great potential for dispersal, this species has been reported from India to north-western Australia, including South Africa, Indonesia, Japan, New Guinea and Hawaii (e.g. van Benthem Jutting 1952, 1964; Solem 1988); in Australia it has been recorded from numerous localities in the Kimberley between Walcott Inlet in the south and the Roper River, NT, in the north (Solem 1988, 1991a) (Figure 3).

\section{Pupisoma circumlitum Hedley, 1897}

Pupisoma circumlitum Hedley, 1897: 44-45; Zilch 1959: 173; Solem 1988: 473-474, figures 17, 24-25; Solem 1991a: 153; Solem 1991b: 250; Stanisic et al. 2010: 100-101.

Imputegla circumlita (Hedley): Iredale 1937: 305.

Pupisoma (Imputegla) circumlitum (Hedley): Merrifield et al. 1977: 114.

\section{MATERIAL EXAMINED}

Australia: Western Australia: Augustus Island (WAM S37470), Boongaree Island (WAM S36326), Coronation Island, northern and southern section (WAM S37473, WAM S37475-8), D'Arcy Island (WAM S37471-2), Middle Osborn Island, western section (WAM S36327, WAM S36917), Sir Graham Moore Island (WAM S36330-4), Southwest Osborn Island, western section (WAM S36328-9), Storr Island (WAM S37906).

\section{REMARKS}

This species was referred to Imputegla in a checklist (Iredale 1937) but this has not been followed by subsequent authors.

\section{DISTRIBUTION AND ECOLOGY}

In Australia this species is widely distributed in coastal regions of south-eastern New South Wales and north-eastern Queensland, the Northern Territory and Western Australia (Solem 1988, Stanisic et al. 2010); it is not rare but is often overlooked. In the Kimberley it has been recorded from 18 localities between Walcott Inlet to Drysdale River National Park and from around Kalumburu (Solem 1991a) (Figure 4).

\section{Nesopupa Pilsbry, 1900}

\section{Nesopupa mooreana (E. A. Smith, 1894)}

Pupa mooreana E. A. Smith, 1894: 97, pl. VII, fig. 25.

Bifidaria mooreana (E. A. Smith): Hedley 1916: 217.

Gastrocopta mooreana (E. A. Smith): Pilsbry 1917 [in 1916-1918]: 160, pl. 30, fig. 4; 1920 [in 1920-1921]: 230-231, pl. 24, figures 6-7.

Australbinula mooreana (E. A. Smith): Iredale 1937: 302; Iredale 1939: 8-9, pl. 1, fig. 4.

Nesopupa mooreana (E. A. Smith): Solem 1988: 477479, figures 33-37; Solem 1991a: 153; Solem 1991b: 249. 


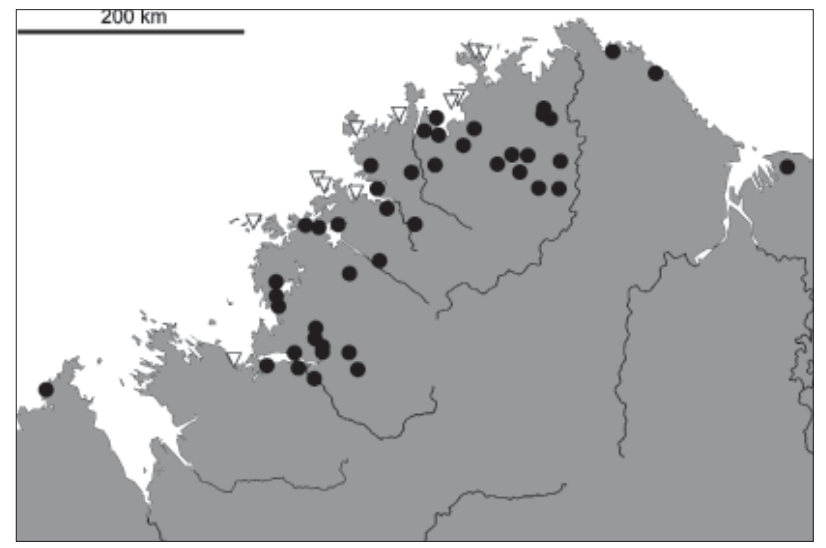

FIGURE 3 Distribution of Pupisoma orcula in the Kimberley: previous records (Solem 1991a), $\nabla$ new records from this survey.

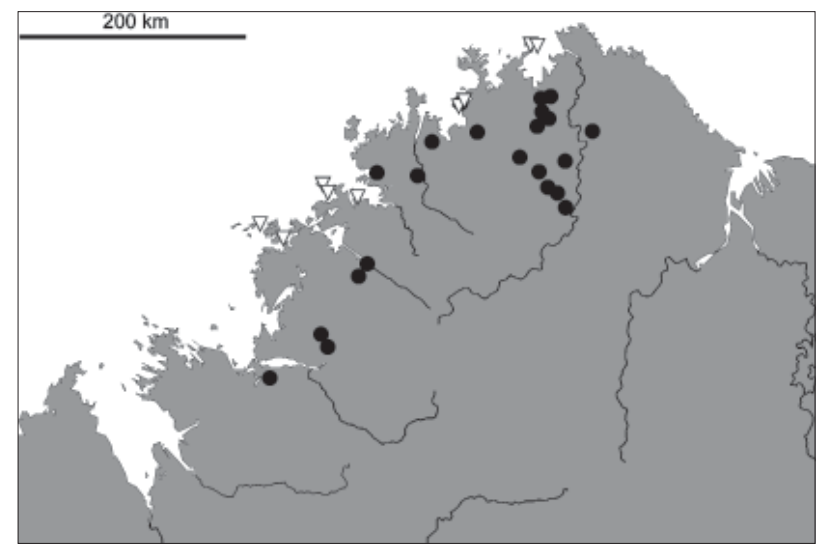

FIGURE 4 Distribution of Pupisoma circumlitum in the Kimberley: previous records (Solem 1991a), $\nabla$ new records from this survey.

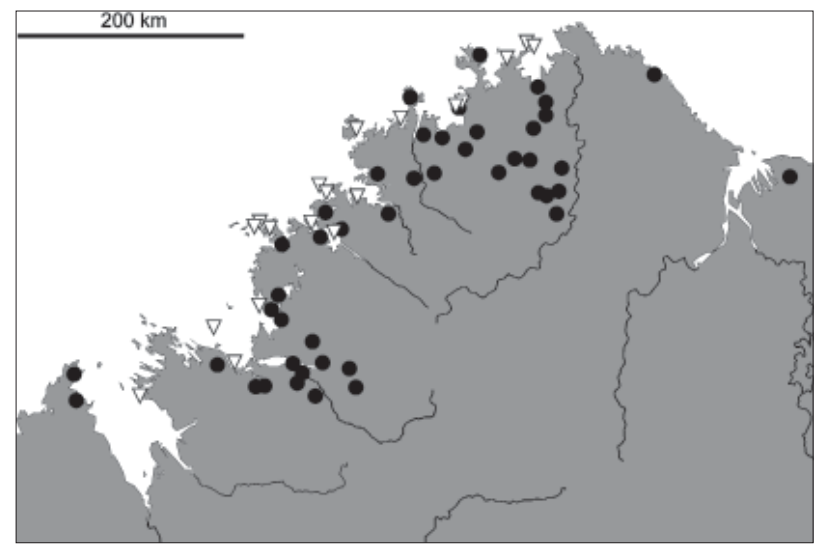

FIGURE 5 Distribution of Nesopupa mooreana in the Kimberley: previous records (Solem 1991a), $\nabla$ new records from this survey.

\section{MATERIAL EXAMINED}

Australia: Western Australia: Augustus Island, northern section (WAM S37474, WAM S37479), Bigge Island (WAM S36262-4), Boongaree Island (WAM S36265-70), Coronation Island, northern and southern section (WAM S37483-5, WAM S37487-502), D'Arcy Island (WAM S37481-2, WAM S37984), Katers Island (WAM S36204-6), Kingfisher Island (WAM S37911-2), Lachlan Island (WAM S49406), Mary Island (WAM S49405), Middle Osborn Island, eastern and western section (WAM S36207-9, WAM S36442, WAM S36913-5), Sir Graham Moore Island (WAM S36217-24), Southwest Osborn Island, western section (WAM S36210-6), St Andrew Island (WAM S37480, WAM S37486), unnamed island, Doubtful Bay (WAM S37910), Uwins Island (WAM S37503-4), Wulalam Island (WAM S37909).

\section{REMARKS}

This taxon was transferred to the genus Nesopupa by Solem (1988), who provided a detailed synonymy based on a comparative analysis of shell features, especially the configuration of apertural barriers. It had been previously placed in Bifidaria Sterki, 1891 by Hedley (1916) and in Australbinula Pilsbry, 1916 by Iredale (1937, 1939). However, Bifidaria is a North American taxon and Australbinula was synonymised with Gastrocopta by Solem (1986). Solem (1988) provided brief comparative remarks as well as distributional data.

\section{DISTRIBUTION AND ECOLOGY}

This species occurs in coastal areas of north-western Western Australia and the Northern Territory (Solem 1988; ABRS 2009). In the Kimberley this species has been recorded from 56 localities between Dampierland in the south-west and the Ningbing Ranges in the northeast (Solem 1991a) (Figure 5).

\section{Gastrocopta Wollaston, 1878}

\section{Gastrocopta pediculus (Shuttleworth, 1852)}

Pupa pediculus Shuttleworth, 1852: 196.

Pupa artensis Montrouzier, 1859: 288, pl. 8, fig. 4.

Pupa moretonensis Cox, 1868: 81.

Pupa (Vertigo) rossiteri Brazier, 1875a: 18

Gastrocopta pediculus ovatula Moellendorff, 1890: 253.

Gastrocopta pediculus (Shuttleworth): Pilsbry 1917 [in 1916-1918]: 158, pl. 26, fig. 1; Solem 1991b: 249; Pokryszko 1996: 1089, fig. 3; Stanisic et al. 2010: 102-103

Gastrocopta pediculus queenslandica Pilsbry, 1917 [in 1916-1918]: 159, pl. 26, fig. 2.

Gastrocopta simplex Solem, 1988: 484, figures 42-45; Solem 1991a: 155-156; Solem 1991b: 249 


\section{MATERIAL EXAMINED}

Australia: Western Australia: Adolphus Island, northern and eastern section (WAM S37538-42, WAM S37604, WAM S37985, WAM S37998), Bigge Island, west and east coast (WAM S36761-4, WAM S42906, WAM S42909), Coronation Island, northern section (WAM S42903), Mary Island (WAM S49401), Sir Graham Moore Island, eastern section (WAM S36765, WAM S42910).

\section{REMARKS}

Solem (1988) proposed a native northern Australian species Gastrocopta simplex and regarded G. pediculus as a recent introduction to Australia. However, $G$. simplex was later synonymised with $G$. pediculus by Pokryszko (1996). The Australian representatives of $G$. pediculus are regarded as native.

\section{DISTRIBUTION AND ECOLOGY}

This species occurs in coastal areas of northern and eastern Australia (north-eastern Western Australia, Northern Territory, Queensland, New South Wales) (Pokryszko 1996). It has been extralimitally recorded from New Caledonia, the Philippines, Cook Islands, Society Islands, Marianas, Hawaii, Tuamotu Islands, Tonga, Vanuatu (= New Hebrides), Solomon Islands, Caroline Islands and Fiji. It is widely distributed in the Kimberley region but records are relatively scarce (Solem 1991a; Pokryszko 1996) (Figure 6).

\section{Gastrocopta stupefaciens Pokryszko, 1996}

Gastrocopta stupefaciens Pokryszko, 1996: 1101-1104, figures $15-17$.

\section{MATERIAL EXAMINED}

Australia: Western Australia: Augustus Island, north-western and southern section (WAM S37562-3, WAM S37568-9), Bigge Island, west and east coast (WAM S36782-6, WAM S36797, WAM S36903, WAM S42896, WAM S42899, WAM S42901, WAM S42908), Boongaree Island, central section (WAM S36787-91, WAM S36804, WAM S42891, WAM S42895), Byam Martin Island (WAM S37565), Coronation Island, northern and southern section (WAM S37573-87, WAM S37593, WAM S42905, WAM S42892), D’Arcy Island, north-western and central section (WAM S37564, WAM S37570-2), Katers Island, west coast (WAM S36792-3), Malby Island (WAM S37991), Melamis Island (WAM S49397), Middle Osborne Island, west and east coast (WAM S36794, WAM S36816, WAM S36904, WAM S42888, WAM S42890, WAM S42894, WAM S42898), Sir Graham Moore Island, eastern section (WAM S42897, WAM S42907, WAM S42912-3, WAM S65202, WAM S65204), Southwest Osborn Island, west coast (WAM S36795, WAM S42889, WAM S42900, WAM S42902), St Andrew Island (WAM S37566-7, WAM S37589), unnamed Island, Vulcan Islands Group (WAM S37990), Uwins Island (WAM S37588, WAM S37603), Wargul Wargul Island (WAM S49402), Wulalam Island (WAM S49398).

\section{REMARKS}

Having long been regarded by earlier workers as identical to Gastrocopta recondita (Tapparone-Canefri, 1883), G. stupefaciens was formally described as a distinct species by Pokryszko (1996) with the type locality of Champagny Island, Bonaparte Archipelago, WA. Pokryszko (1996) lists the distribution of $G$. recondita as extralimital (Philippines, Moluccas and Aru Islands).

\section{DISTRIBUTION AND ECOLOGY}

This species is known only from the extreme north-western region of Australia. Most records are from coastal areas and islands of the north-western Kimberley, with scattered inland records from the north-eastern Kimberley and northern parts of the Northern Territory (Pokryszko 1996) (Figure 7).

\section{Gastrocopta macdonnelli (Brazier, 1875)}

Pupa (Vertigo) macdonnelli Brazier, 1875a: 30; 1875b: 669, pl. 83, fig. 22-23.

Pupa (Vertigo) macleayi Brazier, 1876: 110, 128.

Vertigo macdonnelli (Brazier): Hedley 1888: 65.

Vertigo macleayi (Brazier): Hedley 1888: 65.

Bifidaria macleayi (Brazier): Hedley 1902: 19, pl. 3, fig. 39.

Gastrocopta macdonnelli (Brazier): Pilsbry 1917 [in 19161918]: 162, pl. 27, fig. 9, 11-12; Solem 1988: 492-493, figures 60-61; Solem 1991b: 249; Pokryszko 1996: 1099, figures 11-14; Stanisic et. al. 2010: 102-103.

Gastrocopta macdonnelli macrodon Pilsbry, 1917 [in 19161918]: 164, pl. 27, fig. 7-8, 10.

Australbinula macdonnelli (Brazier): Iredale 1937: 302.

Gastrocopta macrodon Pilsbry: Iredale 1941: 63; Solem 1988: 495-496, figures 62-67; Solem 1991a: 155-156; Solem 1991b: 249.

\section{MATERIAL EXAMINED}

Australia: Western Australia: Augustus Island, north-western and southern section (WAM S37543-8, WAM S37592), Bigge Island, east coast (WAM S36796, WAM S36798-9, WAM S36800-3), Boongaree Island, central section (WAM S36766-71, WAM S36805-9), Coronation Island, northern and southern section (WAM S37550-6, WAM S37594-602), D’Arcy Island (WAM S37549, WAM S37591, WAM S37986), Katers Island, west coast (WAM S36772, WAM S36916), Kingfisher Island (WAM S37982-3), Lachlan Island (WAM S37892, WAM S37967, WAM S49408-9), Low Island (WAM S49412), Malby Island (WAM S37988), 


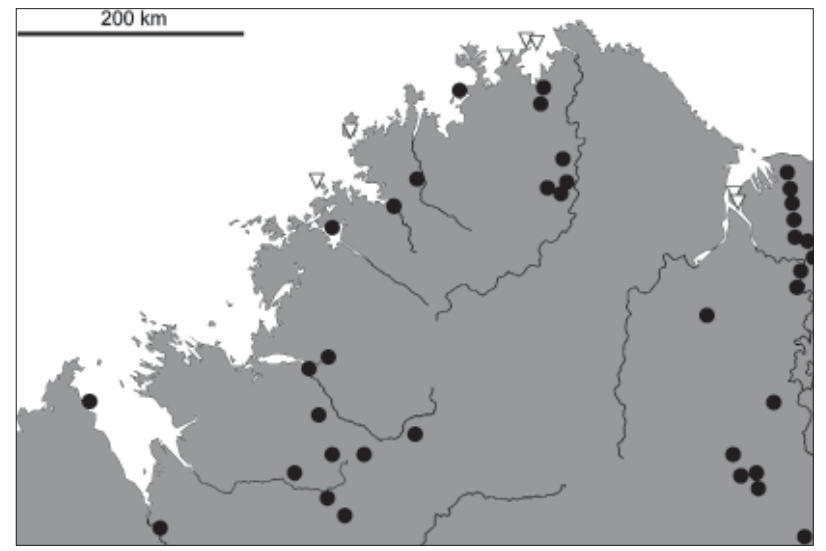

FIGURE 6 Distribution of Gastrocopta pediculus in the Kimberley: previous records (Solem 1991a), $\nabla$ new records from this survey.

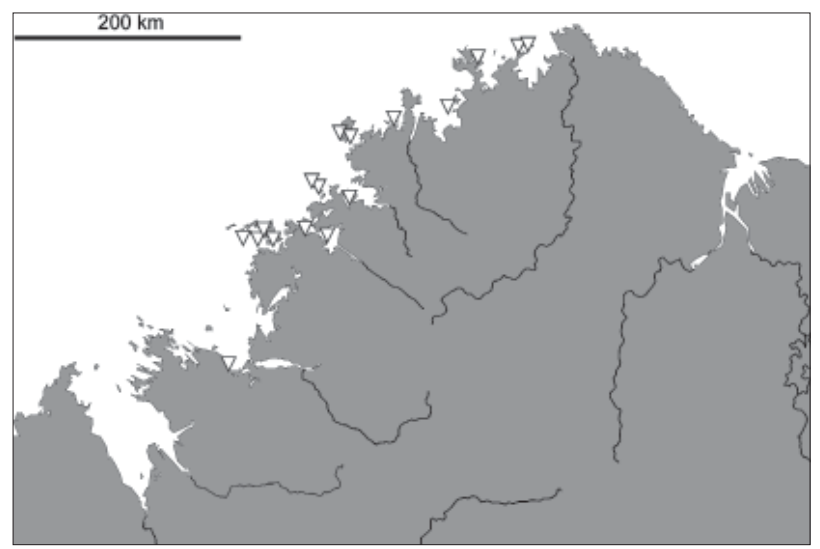

FIGURE $7 \nabla$ new records of Gastrocopta stupefacians in the Kimberley.

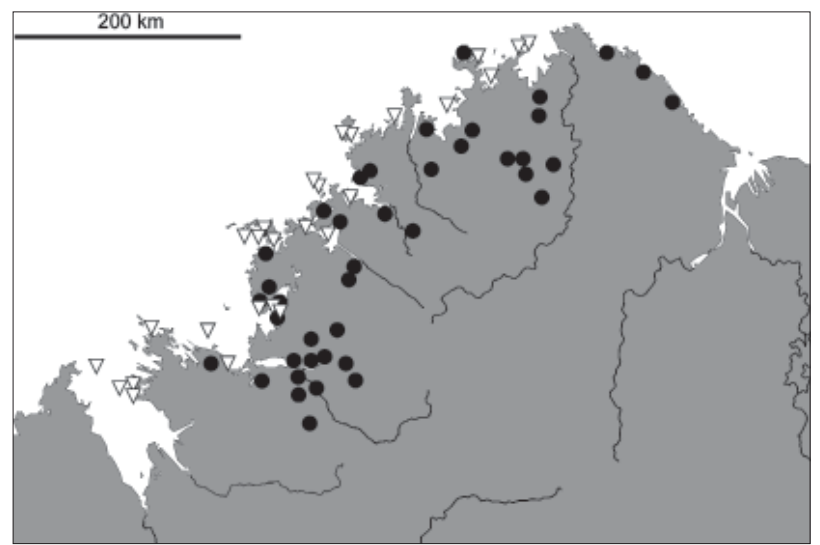

FIGURE 8 Distribution of Gastrocopta macdonneli in the Kimberley: previous records (Solem 1991 a as 'Gastrocopta macrodon'), $\nabla$ new records from this survey.
Mictyis Island (WAM S37989), Middle Osborne Island, west and east coast (WAM S36773-7, WAM S36810-5, WAM S36817-9, WAM S36908-11), Mary Island (WAM S49411), Hidden Island, north-west section (WAM S37971), Long Island, north-west section (WAM S37968), peninsula $7.3 \mathrm{~km} \mathrm{SW}$ of Porter Hill, Cascade Bay (WAM S49407), Sale River, Doubtful Bay (WAM S49410), Sir Graham Moore Island, eastern and western section (WAM S36781, WAM S36825-48), Southwest Osborn Island, west coast (WAM S36778-80, WAM S36820-4, WAM S36912), Storr Island, south-east section (WAM S37972-7), St Andrew Island (WAM S37590), St Patrick Island (WAM S37987), Sunday Island, southern section (WAM S37969), unnamed island, Doubtful Bay (WAM S37978-81), Uwins Island (WAM S37557-61).

\section{REMARKS}

This species shows considerable variation in shell shape and size, and apertural barrier size, within and between populations. Because of this variation, several species and subspecies have been proposed previously but all have since been synonymised with Gastrocopta macdonnelli by Pokryszko (1996).

\section{DISTRIBUTION AND ECOLOGY}

This species occurs in coastal areas of northern Australia, including north Western Australia, the Northern Territory and north-eastern Queensland. Extralimitally it has been recorded from Papua New Guinea (Pokryszko 1996). It is widely distributed in the Kimberley, with most records within the north-western coastal region (Solem 1991a; Pokryszko 1996) (Figure 8).

\section{Gastrocopta kessneri (Solem, 1988)}

Pumilicopta kessneri Solem, 1988: 499-500, figures 85-87; Solem 1991a: 159; Solem 1991b: 250.

Gastrocopta (Pumilicopta) kessneri (Solem): Pokryszko 1996: 1113, figures 26-28.

\section{MATERIAL EXAMINED}

Australia: Western Australia: Augustus Island, north-western and southern section (WAM S37506-9, WAM S37512, WAM S37515), Bigge Island, east coast (WAM S36225-6), Boongaree Island, central section (WAM S36227-35), Coronation Island, northern and southern section (WAM S37518-34, WAM S37997), D'Arcy Island (WAM S37510, WAM S37516, WAM S37517, WAM S37994), Katers Island, west coast (WAM S36236-41), Malby Island (WAM S37996), Middle Osborne Island, west and east coast (WAM S36242-9, WAM S36905-6), peninsula ca 8 km SE of St. Patrick Island, Saint George Basin (WAM S37995), Sale River, Doubtful Bay (WAM S49403), Sir Graham Moore Island, eastern and western section (WAM S36258-61), Southwest Osborn Island, west coast (WAM S36250-7, WAM S36907), Storr Island, south-east section (WAM S37902-4), St Andrew Island (WAM S37511, WAM 
S37513-4), St Patrick Island (WAM S37993), Uwins Island (WAM S37535-7), Wargul Wargul Island (WAM S49363, WAM S49404).

\section{REMARKS}

Solem (1988) proposed a new genus, Pumilicopta, which was later given subgeneric rank by Poykryszko (1996), who could not detect characters sufficient to distinguish it at the generic level.

\section{DISTRIBUTION AND ECOLOGY}

This species occurs in coastal areas and islands of north Western Australia, with only a few scattered records from the coastal Northern Territory. It is widely distributed in the Kimberley, with most records being located within the north-western coastal region (Solem 1991a) (Figure 9).

\section{Pupoides Pfeiffer, 1854}

\section{Pupoides pacificus (Pfeiffer, 1846)}

Pupa pacifica Pfeiffer, 1846: 31; Hedley and Musson 1892: 558; E. A. Smith 1894: 96 (partim).

Bulimus pacificus (Pfeiffer): Cox 1868: 68-69, pl. 13, fig. 3; Brazier 1876: 272.

Pupoides pacificus (Pfeiffer): Pilsbry 1900: 426, fig. 1; Hedley 1916: 68 (partim); Pilsbry 1920 [in 19201921]: 1414, pl. 15, figures 11-15 (partim); Solem 1988: 513-516, figures 108-114; Solem 1991a: 160; Solem 1991b: 250; Stanisic et al. 2010: 98-99.

Themapupa pacifica (Pfeiffer): Iredale 1937: 304.

Themapupa anapacifica Iredale, 1939: 10, pl. 1, fig. 9.

Themapupa dirupta Iredale, 1939: 11, pl. 1, fig. 8.

Themapupa comperta Iredale, 1940: 235.

Pupoides (Themapupa) anapacifica (Iredale): Merrifield et al. 1977: 114.

\section{MATERIAL EXAMINED}

Australia: Western Australia: Adolphus Island (WAM S37426-30), Bigge Island (WAM S36044-70, Boongaree Island (WAM S36048-52), Bougainville Peninsula (WAM S49375), Coronation Island, northern and southern section (WAM S37417-25), D'Arcy Island (WAM S37416), Katers Island (WAM S56053-4), Lachlan Island (WAM S49391-2), Low Island (WAM S49376), Mary Island (WAM S49374), Middle Osborn Island, eastern and western section (WAM S36055-8), Sale River, Doubtful Bay (WAM S49315), Sir Graham Moore Island, eastern and western section (WAM S36062-76), Southwest Osborn Island, western section (WAM S36059-61), Storr Island (WAM S37893).

\section{REMARKS}

The present generic treatment was suggested by Pilsbry (1900). Iredale (1930) named a new genus, Themapupa, for the Australian species, and later maintained this genus despite its subsequent rejection by Pilsbry (1921). Smith and Kershaw (1979) and Solem (1986, 1988) maintained Pilsbry's (1900) generic treatment. The four Themapupa species described by Iredale $(1939,1940)$ were regarded as synonyms of Pupoides pacificus by Solem (1988) although he remarked that subspecies may exist. A sinistrallycoiling population of Pupoides on Cassini Island in the Kimberley was assigned to the dextrally-coiling Pupa pacifica by Smith (1894), but later separated as $P$. pacificus var. sinistralis by Pilsbry (1921). Iredale (1939) promoted the sinistral population to species status as Themapupa sinistralis. This decision was subsequently rejected by Solem (1986) who maintained Pilsbry's (1921) treatment. Solem (1988) later placed Smith's (1894) sinistral population in P. pacificus. However, other dextral and sinistral Pupoides specimens being found in sympatry in central and southern Australia have been regarded as separate species and it is considered likely that the Cassini Island sinistral population will also prove to represent a distinct species. Sinistral specimens have since been found on other Kimberley Islands (Whisson, unpublished data).

\section{DISTRIBUTION AND ECOLOGY}

This species is widely distributed in the interior and most of the drier northern to north-eastern regions of Australia, including Western Australia, Queensland, the Northern Territory and north-western New South Wales (Solem 1988; ABRS 2009; Stanisic et al. 2010). In Western Australia it has been recorded from just east of Kununurra southward to Quondong Point, north of Broome, with a single isolated record from the Chichester Range in the Pilbara (Solem 1988) (Figure 10).

\section{Family Cerastidae Wenz, 1923}

\section{Amimopina Solem, 1964}

\section{Amimopina macleayi (Brazier, 1876)}

Bulimus macleayi Brazier, 1876: 108.

Amimopina macleayi (Brazier): Solem 1964: 115-9; 1973: figures 9-10; Merrifield et al. 1977: 115; Solem 1988: 519, fig. 150; Stanisic et al. 2010: 112-113.

Bulimus beddomei Brazier, 1880: 385.

\section{MATERIAL EXAMINED}

Australia: Western Australia: Augustus Island, northern section (WAM S37681), Bigge Island (WAM S36087-90, WAM S36659-60, WAM S36886-8, WAM S36936), Boongaree Island (WAM S36091-2), Coronation Island, southern section (WAM S36997, WAM S37167-73, WAM S37680), D’Arcy Island (WAM S37163-4), Middle Osborn Island, eastern and 


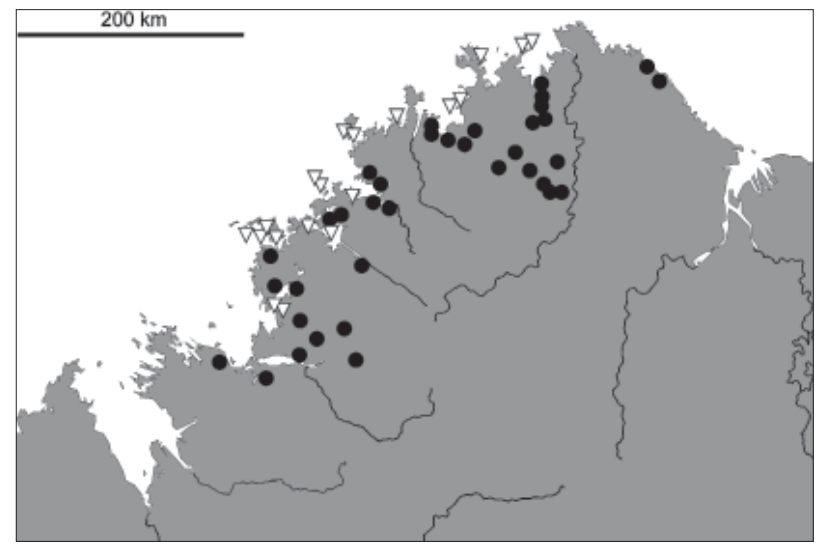

FIGURE 9 Distribution of Gastrocopta (Pumilicopta) kessneri in the Kimberley: previous records (Solem 1991a), $\nabla$ new records from this survey.

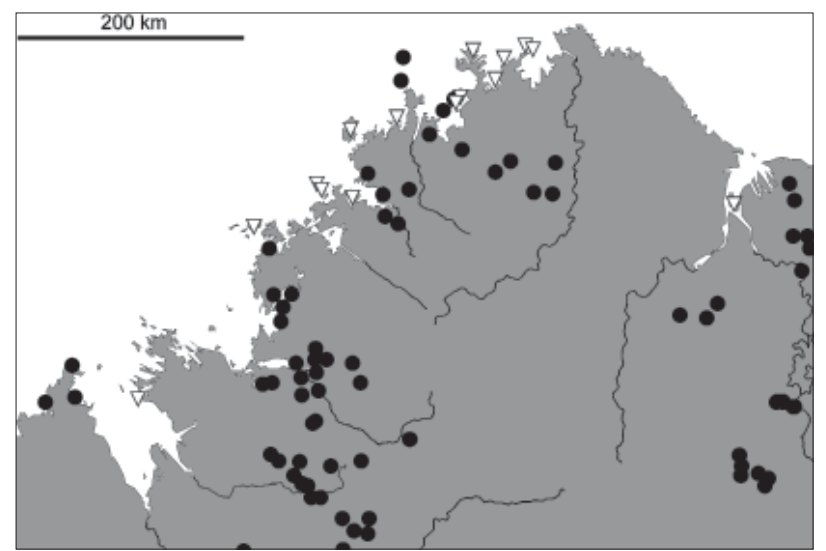

FIGURE 10 Distribution of Pupoides pacificus in the Kimberley: previous records (Solem 1991a), $\nabla$ new records from this survey.

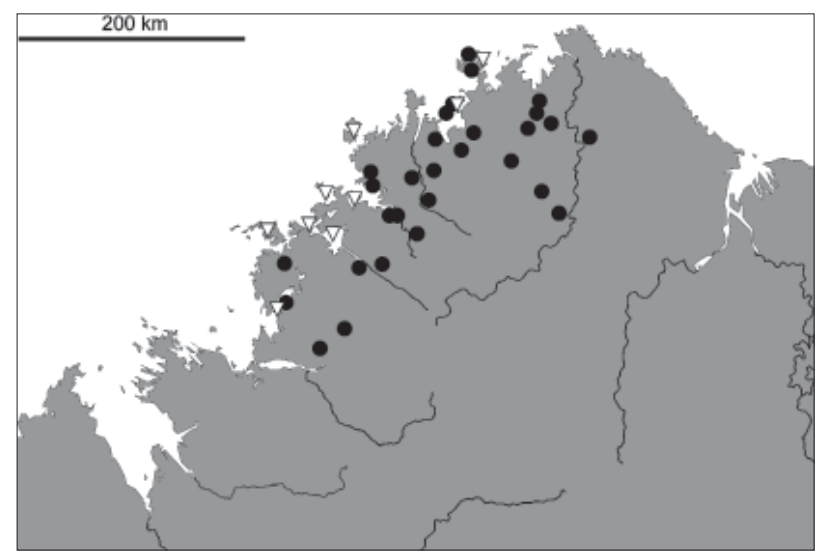

FIGURE 11 Distribution of Amimopina macleayi in the Kimberley: previous records (Solem 1991a), $\nabla$ new records from this survey. western section (WAM S36093-102, WAM S36441, WAM S36661-4, WAM S36677-82, WAM S36889-93), Southwest Osborn Island, eastern and western section (WAM S36103-9, WAM S36665-70, WAM S36894-5), Storr Island (WAM S37894-5), St Andrew Island (WAM S36996, WAM S37165-6), Uwins Island (WAM S37174, WAM S37086), Wargul Wargul Island (WAM S49298).

\section{REMARKS}

Solem's (1964) taxonomic revision of this species was based on anatomical data, and he suggested placement in the new genus Amimopina. He also suggested the synonymy of Bulimus beddomei. Further distributional data was subsequently presented by Solem (1988, 1991a).

\section{DISTRIBUTION AND ECOLOGY}

The species was originally described from Yule Island, Papua New Guinea, but has also been recorded from northern Australia, including coastal regions of Western Australia (Pilbara, Kimberley), the Northern Territory and northern and coastal north-eastern Queensland, including the Torres Strait Islands (Solem 1988, 1991a; Stanisic et al. 2010) (Figure 11).

\section{Family Subulinidae P. Fischer and Crosse, 1877}

\section{Eremopeas Pilsbry, 1906}

\section{Eremopeas interioris (Tate, 1894)}

Stenogyra interioris Tate, 1894: 191; Tate 1896: 203.

Pseudopeas (Eremopeas) interioris (Tate): Pilsbry 1906: 120, pl. 25, figures 17-18.

Eremopeas interioris (Tate): Solem 1988: 526-529, figures 139, 141-148.

\section{MATERIAL EXAMINED}

Australia: Western Australia: Augustus Island, northern and southern section (WAM S37205-9, WAM S37213), Bigge Island (WAM S36110-7), Boongaree Island (WAM S36118-30), Byam Martin Island (WAM S37210), Coronation Island, northern and southern section (WAM S37215-39), D’Arcy Island (WAM S37214), Gale Island (WAM S49056), Kingfisher Island (WAM S37926-8), Lachlan Island (WAM S37913-4, WAM S49380-1), Long Island, King Sound (WAM S37915), Mictyis Island (WAM S49057), Middle Osborn Island, eastern and western section (WAM S36131-44, WAM S36932-4), Peninsula 7.3 km SW of Porter Hill, Cascade Bay (WAM S49313), Sale River mouth, Doubtful Bay (WAM S49382, WAM S49314), Southwest Osborn Island, western section (WAM S36145-90), St Andrew Island (WAM S37211-2), St Patrick Island (WAM S49055), Storr Island (WAM S37918-21), Sunday Island (WAM S37916-7), unnamed island, Doubtful Bay (WAM S37922-4, WAM S37981), Uwins Island (WAM S372401), Wargul Wargul Island (WAM S49370). 


\section{REMARKS}

The species was placed in Eremopeas by Pilsbry (1906), which was followed by Solem (1988, 1991a). Solem (1988) provided a detailed description of shell features as well as many distributional records. Only one other subulinid species, E. tuckeri (Pfeiffer, 1846), is known to be endemic to Australia, but it is confined to the Northern Territory and eastern Australia (Solem 1988; Smith 1992; Stanisic et al. 2010).

\section{DISTRIBUTION AND ECOLOGY}

This species is endemic to Australia, where it is widely distributed throughout warmer regions, being recorded from Central Australia, Northern Territory and Queensland as well as from the Pilbara and Kimberley, Western Australia (Solem 1988) (Figure 12).

\section{Family Charopidae Hutton, 1884}

\section{Discocharopa Iredale, 1913}

\section{Discocharopa aperta (Moellendorff, 1888)}

\section{Patula aperta Moellendorff, 1888: 89.}

Discocharopa aperta (Moellendorff): Solem 1983: 76-81; Solem 1984: 164-165, figures 9, 10, 22-27; Solem 1988: 538, figures 157-160; Stanisic et al. 2010: 216-217.

Endodonta (Charopa) planorbulina Tate, 1896: 187, pl. 17, fig. 3 .

Endodonta concinna Hedley, 1901: 729, pl. 48, figures $1-3$.

Discocharopa microdiscus van Benthem Jutting, 1964: 11 .

\section{MATERIAL EXAMINED}

Australia: Western Australia: Augustus Island, northern section (WAM S37340), Boongaree Island (WAM S36082), Coronation Island, northern and southern section (WAM S37343-5), Kingfisher Island (WAM S37908), Southwest Osborn Island, western section (WAM S36083), St Andrew Island (WAM S37341-2), Storr Island (WAM S37907).

\section{REMARKS}

The synonymy of Endodonta (Charopa) planorbulina and E. concinna has been suggested by Solem (1984) based on a study of the type material. This charopid species appears to have closer affinities with Indonesian rather than with eastern Australian confamilial species (Solem, 1984).

\section{DISTRIBUTION AND ECOLOGY}

The species has a wide distribution in south-eastern Asia and tropical Australasia, including the Philippines, New Guinea, and northern Australia. The Australian distribution was summarized by Solem $(1984,1988)$ as generally scattered with records from Western Australia (Kimberley), the Northern Territory (Katherine area), central (MacDonnell Range, Alice Springs) and eastern

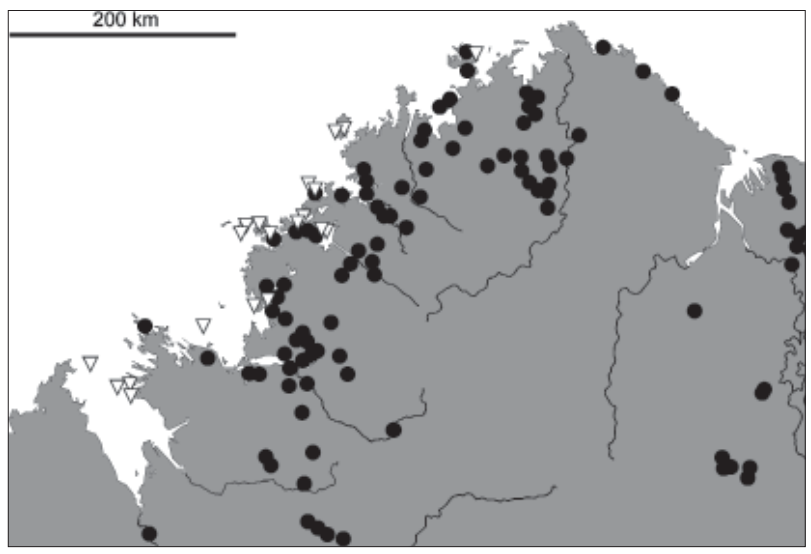

FIGURE 12 Distribution of Eremopeas interioris in the Kimberley: previous records (Solem 1991a), $\nabla$ new records from this survey.

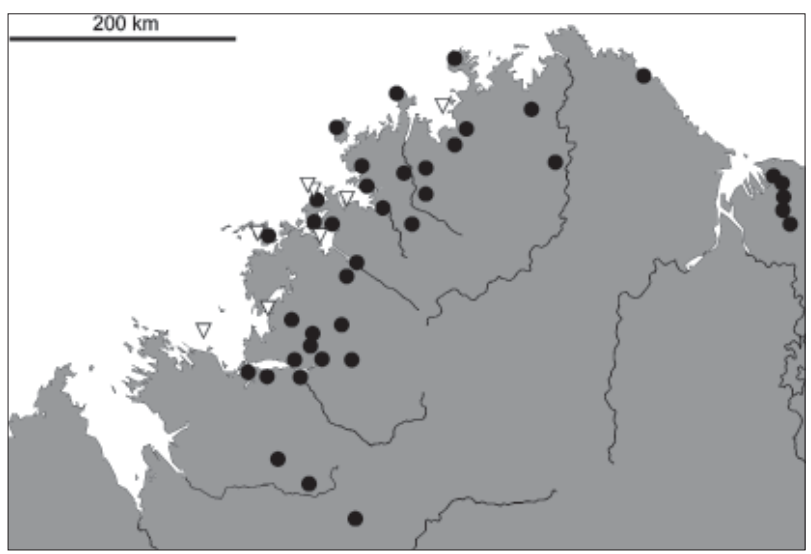

FIGURE 13 Distribution of Discocharopa aperta in the Kimberley: previous records (Solem 1991a), $\nabla$ new records from this survey.

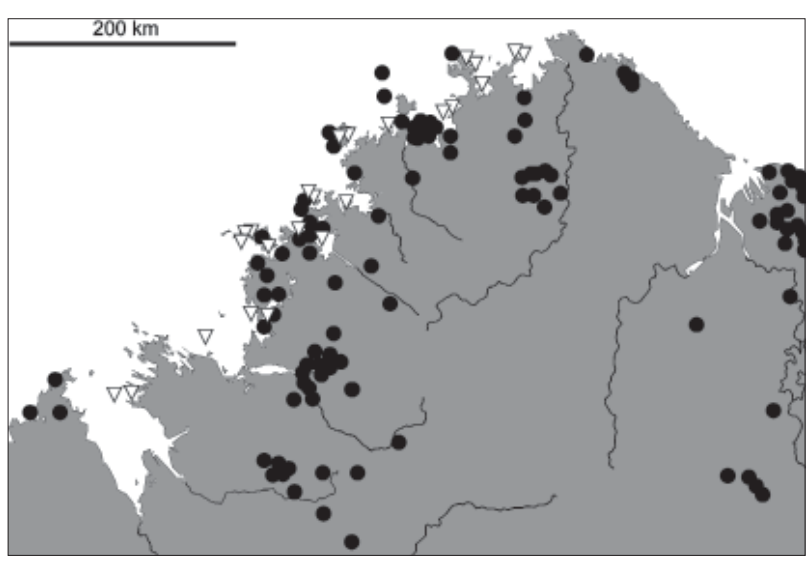

FIGURE 14 Distribution of Stenopylis coarctata in the Kimberley: previous records (Solem 1991a as 'Gastrocopta macrodon), $\nabla$ new records from this survey. 
Australia (Queensland through to northern New South Wales). With respect to the Kimberley and adjacent areas of the Northern Territory, Solem (1984) remarked on its absence from the Prince Regent River, Mitchell Plateau, Kalumburu, Drysdale and Katherine areas. Solem $(1988,1991 \mathrm{a})$ added records from Katherine, the Roper River and throughout the Kimberley, where the species has been found in both rainforest patches and drier limestone areas (Figure 13).

\section{Family Helicodiscidae H.B. Baker, 1927 \\ Stenopylis Fulton, 1914}

\section{Stenopylis coarctata (Moellendorff, 1894)}

Plectopylis coarctata Moellendorff, 1894 [in Quadras and Moellendorff 1894]: 113.

Stenopylis coarctata (Moellendorff): Solem 1984: 15963, figures 1-8, 11-21; Solem 1988: 535-537, figures 153-156; Stanisic et al. 2010: 276.

Planispira hemiclausa Tate, 1894: 192.

Helix (Polygyra) microdiscus Bavay, 1908: 283.

\section{MATERIAL EXAMINED}

Australia: Western Australia: Augustus Island (WAM S37303-8, WAM S37313), Bigge Island (WAM S36271-83), Boongaree Island (WAM S 36284-9), Bougainville Peninsula (WAM S49368), Byam Martin Island (WAMS 37309), Coronation Island (WAM S37316-34, WAM S49051), D'Arcy Island (WAM S37314-5, WAM S37505, WAM S49048, WAM S49052), Gale Island (WAM S49050), Katers Island (WAM S36290-5, WAM S36727, WAM S36941), Kingfisher Island (WAM S37948-50), Long Island, King Sound (WAM S37937), Low Island (WAM S49369), Malby Island (WAM S49049), Middle Osborn Island (WAM S36296-307, WAM S36937-40), Storr Island (WAM S 37938-43), Sir Graham Moore Island (WAM S36316-25), Southwest Osborn Island (WAM S3630815, WAM S36942-3), St Andrew Island (WAM S373102), unnamed island, Doubtful Bay (WAM S37945-7), Uwins Island (WAM S37335), Wargul Wargul Island (WAM S49366-7).

\section{REMARKS}

The synonymy of Planispira hemiclausa Tate, 1894 and Helix (Polygyra) microdiscus Bavay, 1908 with Stenopylis coarctata (Moellendorff, 1894) was suggested by Solem (1984). Data on shell morphology and the distribution of this flattened, minute terrestrial snail has been presented by Solem $(1984,1988)$ and Stanisic et al. (2010).

\section{DISTRIBUTION AND ECOLOGY}

Although records are scattered, this species apparently has a wide distribution, which includes the Philippines, large areas in Indonesia, New Guinea, the Solomon Islands, and northern Australia (Solem 1984, 1988). In

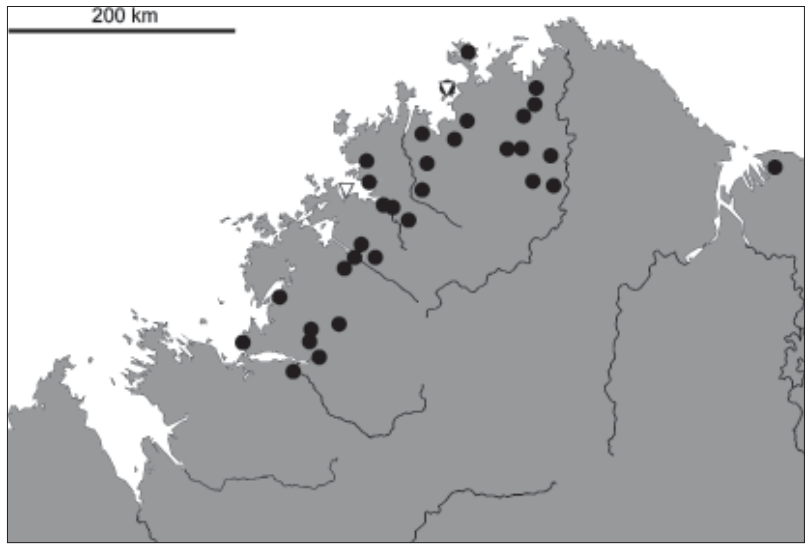

FIGURE 15 Distribution of Coneuplecta microconus in the Kimberley: previous records (Solem 1991 a as 'Gastrocopta macrodon'), $\nabla$ new records from this survey.

Australia it has been found throughout the Kimberley as well as in many parts of the Northern Territory, Queensland, and central Australia (Solem 1984, 1988, 1991a; Stanisic et al. 2010) (Figure 14). Recently, it has been recorded from Cape Range in Western Australia (Slack-Smith 1993).

\section{Family Euconulidae Bourguignat, 1877}

\section{Coneuplecta Moellendorff, 1893}

\section{Coneuplecta microconus (Mousson, 1865)}

Nanina microconus Mousson, 1865: 192.

Coneuplecta microconus (Mousson): van Benthem Jutting 1964: 21-2.

Coneuplecta (Sitalina) microconus (Mousson): H. B. Baker 1941: 236-7, pl. 44, figures 10; Solem 1988: 545-546, figures 174, 179-180.

Sitala bandongensis O. Boettger, 1890: 141-142, pl. 5, figures 3, 3a-3b.

Coneuplecta bandongensis (Boettger): van Benthem Jutting 1950: 388-90, figures 4-5; 1958: 329.

\section{MATERIAL EXAMINED}

Australia: Western Australia: Boongaree Island (WAM S36085, WAM S36931), Middle Osborn Island, eastern section (WAM S36086).

\section{REMARKS}

Familial placement of this genus has been controversial. Here we follow the latest available revision by Hyman and Ponder (2010).

\section{DISTRIBUTION AND ECOLOGY}

This species was described from Fiji and subsequently 
reported from western Irian Jaya (van Benthem Jutting 1964), throughout the Indonesian Archipelago (van Benthem Jutting 1950, 1958), Tonga, Vanuatu and Australia (Solem 1988). Within Australia it has been recorded from NE Queensland (Stanisic et al. 2010), the wetter areas of the Northern Territory and the Kimberley north of Walcott Inlet (Solem 1991a) (Figure 15). The species aestivates sealed to twigs, bark or leaves in litter and is restricted to rainforest and vine thickets (Solem 1991a; Stanisic et al. 2010).

\section{Family Helicarionidae Bourguignat, 1877 \\ Westracystis Iredale, 1939}

\section{Westracystis lissus (E. A. Smith, 1894)}

Lamprocystis lissa E.A. Smith, 1894: 86.

Microcystis lissa (E.A. Smith): Hedley 1916: 71.

Westracystis lissus (E.A. Smith): Iredale 1933: 56; Iredale 1937: 6; Iredale 1939: 44; Solem 1982: 178-83, figures 1-5, 12-14, 16, 18; Solem 1988: 554-555.

Westracystis tentus Iredale 1939: 44.

\section{MATERIAL EXAMINED}

Australia: Western Australia: Adolphus Island (WAM S37152-7), Augustus Island, northern and southern section (WAM S37091-7, WAM S37114-6), Bigge Island, eastern and western section (WAM S36150-6, WAM S36685, WAM S36920), Boongaree Island (WAM S36157-66, WAM S36561, WAM S36757, WAM S49059), Bougainville Peninsula (WAM S49379), Byam Martin Island (WAM S37076, WAM S37107), Coronation Island, northern and southern section (WAM S37124-46), D'Arcy Island (WAM S37077, WAM S37090, WAM S37098-106, WAM S37108, WAM S37117-23, WAM S49058), Gale Island (WAM S49062), Katers Island (WAM S36167-9, WAM S36686-9, WAM S36759), Kingfisher Island (WAM S37964-5), Malby Island (WAM S49061), Middle Osborn Island, eastern and western section (WAM S36170-7, WAM S36690-2, WAM S36921-3, WAM S36951), peninsula $7.3 \mathrm{~km}$ SW of Porter Hill, Cascade Bay (WAM S49316), Sale River, Doubtful Bay (WAM S49317, WAM S49384), Sir Graham Moore Island, eastern and western section (WAM S36186-203, WAM S36700-1), Southwest Osborn Island, western section (WAM S36178-85, WAM S36693-9), St Andrew Island (WAM S3710913), Storr Island (WAM S37957-61), Sunday Island (WAM S37787-9, WAM S37810, WAM S37951, WAM S37953-5), unnamed island, Baylis Island Group (WAM S49319), unnamed island, Doubtful Bay (WAM S379623), unnamed island, Vulcan Islands Group (WAM S49060), unnamed island, Talbot Bay (WAM S49386), Uwins Island (WAM S37078, WAM S37147-51), Wargul Wargul Island (WAM S 49377-9, WAM S49385), Wulalam Island (WAM S37956, WAM S49318).

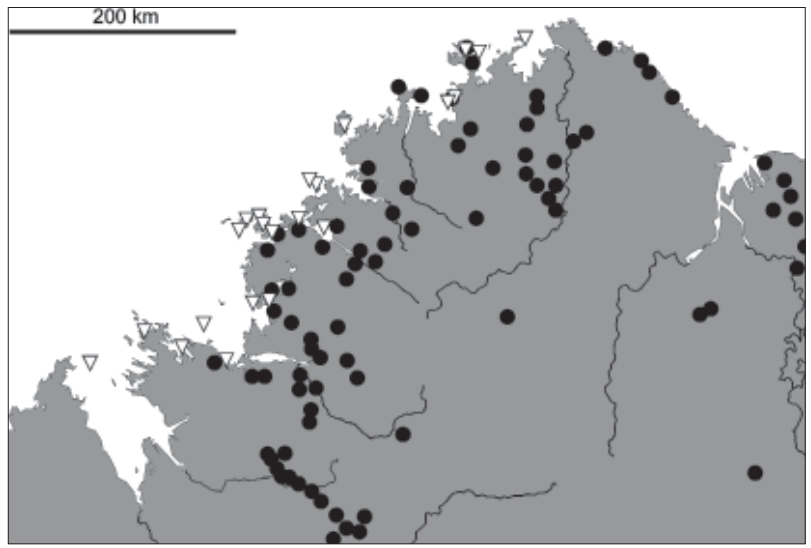

FIGURE 16 Distribution of Westracystis lissus in the Kimberley: previous records (Solem 1991a), $\nabla$ new records from this survey.

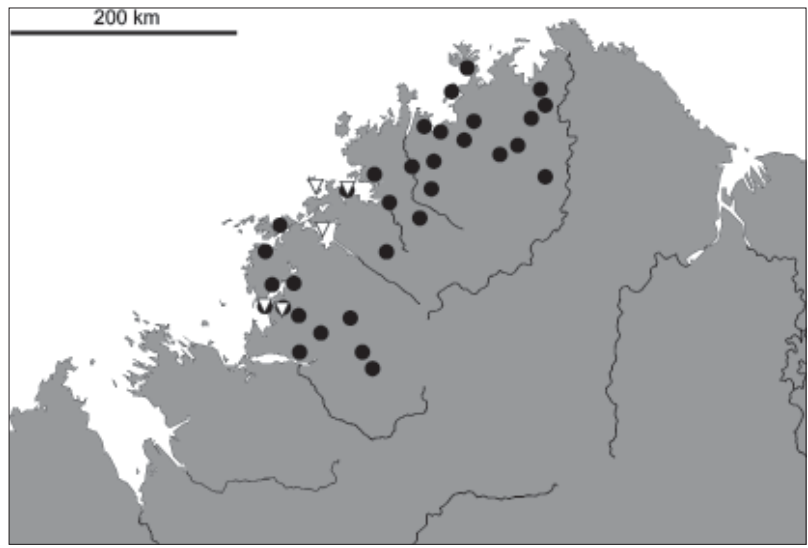

FIGURE 17 Distribution of Wilhelminaia mathildae in the Kimberley: previous records (Solem 1991a), $\nabla$ new records from this survey.

\section{REMARKS}

This species was originally placed in Lamprocystis, a euconulid taxon, and was subsequently affiliated with Microcystis by Hedley (1916), also a member of the Euconulidae. Eventually, the species was placed in the new genus Westracystis by Iredale (1939). Solem (1982) revised its taxonomy based on a comparative anatomical study and synonymised $W$. tentus with $W$. lissus. Hyman and Ponder (2010) also published a description of the anatomy and followed the taxonomy suggested by Solem (1982)

\section{DISTRIBUTION AND ECOLOGY}

This species is widely distributed in the Kimberley, Western Australia, and adjacent areas of the Northern Territory (Solem 1982, 1991a) (Figure 16), where it has been found at a large number of localities, most of which lie within the area characterised by the $500 \mathrm{~m}$ rainfall isohyets. Its distribution becomes more scattered towards the dryer south-eastern section of the Kimberley 
(Solem 1982). Specimens have been found in a wide range of habitats from very dry to moist conditions (Solem 1991a).

\section{Wilhelminaia mathildae Preston, 1913}

Wilhelminaia mathildae Preston, 1913: 435; van Benthem Jutting 1964: 28; Solem 1960: 43; Solem 1988: 547-548, figures 185-189; Stanisic et al. 2010: $344-345$.

\section{REMARKS}

Solem (1988) provided comparative data on shell morphology and summarised the known distribution of this species. The familial placement of Wilhelminaia is dubious - placement within the Euconulidae has been suggested by Hyman and Ponder (2010) based on a morphology-based revision, whereas Stanisic et al. (2010) referred it to the family Microcystidae.

\section{MATERIAL EXAMINED}

Australia: Western Australia: Boongaree Island (WAM S36084), Coronation Island, southern section (WAM S37336-9), St Patrick Island (WAM S37992), Storr Island (WAM S37896-8), Sale River, Doubtful Bay (WAM S49389).

\section{DISTRIBUTION AND ECOLOGY}

This species was originally described from Obi, in the Moluccas region of Indonesia and has subsequently been recorded from other sites in the Moluccas and in Papua New Guinea, the Solomon Islands and Vanuatu (=New Hebrides). Within Australia, it is widespread along the eastern coast from southern NSW to northern Queensland (Stanisic et al. 2010), in the Northern Territory north of the Roper River and in the wetter parts of the Kimberley (Solem 1988) (Figure 17).

\section{DISCUSSION}

Seventeen terrestrial and four freshwater species of non-camaenid, non marine molluscs have been recorded from the surveyed islands. Because most of these islands had never been previously surveyed, most observations reported here are first records. Some extra records from the additional collection sites mentioned in the materials and methods chapter are also listed. Sampling at these additional sites was not conducted with the same level of effort as that expended at the island sites. Consequently, these anecdotal records are not considered comparable to the island sampling, and are not discussed further in regard to the faunal patterns on islands of the Kimberley coast.

The most comprehensive survey of the land snail fauna of the Kimberley had been undertaken as a part of the Kimberley Rainforest Survey in 1987 (Solem 1991a; Solem and McKenzie 1991). During this survey, which was conducted to document faunal patterns across rainforest patches in the Kimberley, 22 species of terrestrial non-camaenid snails were found. Five of these species, Elasmias manilense (Dohrn, 1863), E. terrestris (Brazier, 1876), Glyptopupoides egregia (Hedley \& Musson, 1892), Succinea sp., Liardetia scandens (Cox, 1872), were not recorded during the present Kimberley Island Survey. In turn, the new assimineid species, not recorded previously, has been found on one of the islands. Hence, according to current knowledge, the islands support at least $77 \%$ of the land snail fauna of the entire Kimberley. It has been shown that for the Kimberley in general, the local species richness of terrestrial gastropod assemblages is significantly correlated with habitat attributes, such as rainfall, temperature and substrate (Solem 1991). Of these, rainfall is the most significant factor influencing the patterns in the non-camaenid gastropods (Solem and McKenzie 1991; Gibson and Köhler 2012).

In accordance with the faunal patterns found across the Kimberley mainland, we observed a variation in species richness on the islands along a geographical gradient. On single islands between none and 15 (with an average of eight) species of non-camaenid land snails were found (Table 1). Four of the islands, Middle and Southwest Osborn Islands, Boongaree Island and Coronation Island, support at least 13 species of noncamaenid land snails, which is equivalent to more than $75 \%$ of all species recorded on the Kimberley islands, and to $60 \%$ or more of the species recorded from the entire Kimberley region. Thus, in terms of faunal representativeness of the Kimberley islands compared to the mainland fauna, it appears that relatively few islands harbour a significant proportion of the overall species diversity of non-camaenid land snails. Islands that support large numbers of species $(>11)$ are generally situated within the high rainfall area that is delimited by the annual $1,000 \mathrm{~mm}$ isohyet as shown by McKenzie (1991, Figure 1). In turn, islands that support very low numbers of species $(<4)$ are predominantly situated in areas that receive less annual rainfall (between 800 and $1,000 \mathrm{~mm}$ ). The only notable exception to this rule is Byam Martin Island where only four species were found although the island is situated within an area that receives more than 1,200 $\mathrm{mm}$ of annual precipitation. However, as sampling on this island was not completed due to logistical problems, the low number of species could be attributed to incomplete sampling rather than a real paucity of species.

Overall the patterns of species richness on the islands seem to follow the same trajectories found on the mainland, with annual rainfall being the most important factor; for a detailed analysis of distributions refer to Köhler and Gibson (2012)

In contrast to terrestrial snails, the fauna of freshwater snails in the Kimberley has never been comprehensively surveyed. Thus, our understanding of the faunal patterns of freshwater molluscs in the Kimberley is incomplete. Even though the fauna is certainly depauperate, the Kimberley and the immediately adjacent regions of north Western Australia do support some endemic 


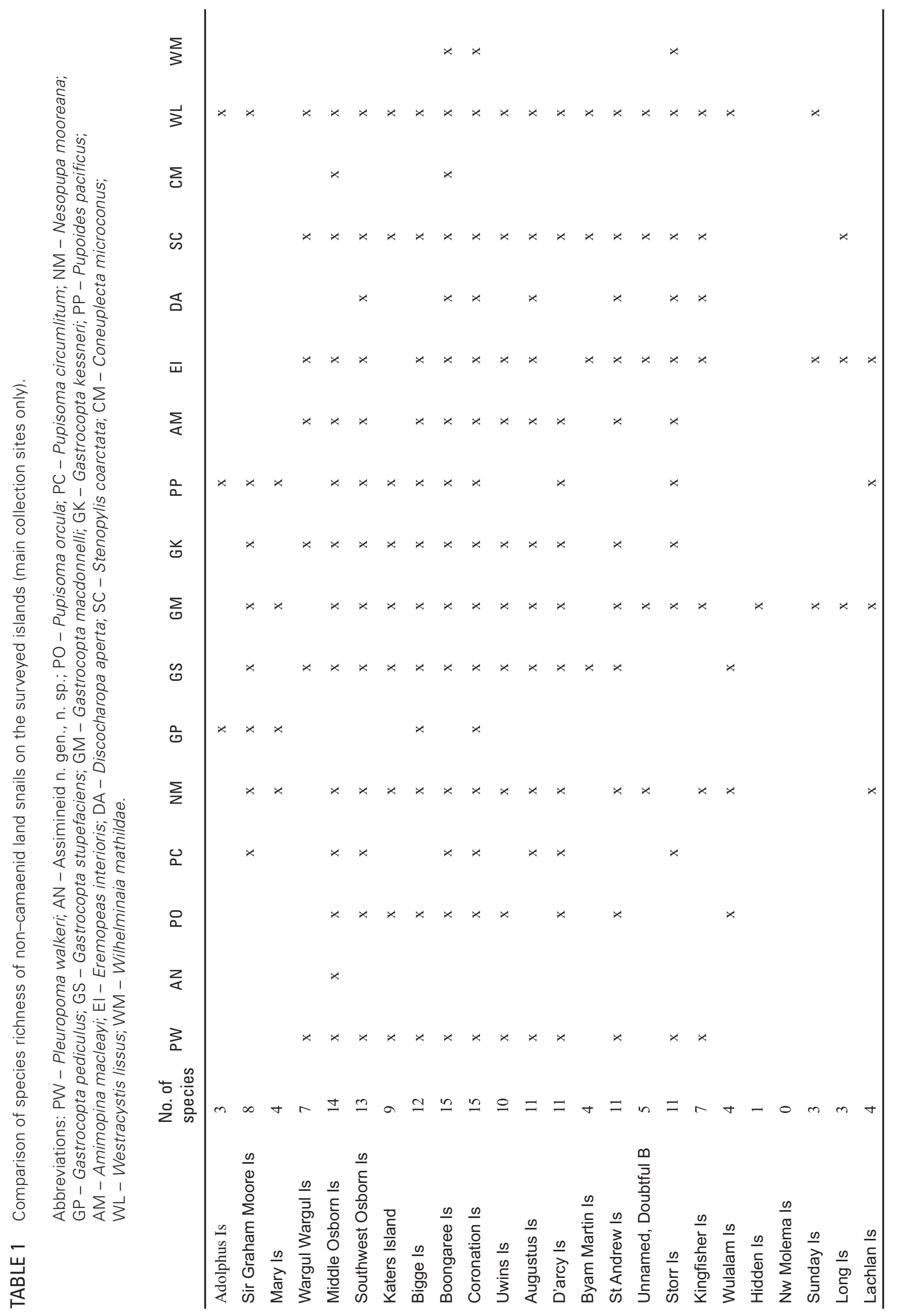


species, such as Bayardella johni. However, only four islands, Wargul Wargul, Southwest Osborn, Bigge and Coronation Islands, have permanent freshwater bodies. More importantly, rivers which are significant freshwater habitats, are absent. Therefore, it is not surprising that only four freshwater species were recorded and that larger, predominantly riverine groups, such as hyriid bivalves and thiarid gastropods, are entirely absent.

\section{ACKNOWLEDGEMENTS}

Thanks are due to two anonymous reviewers for carefully reading an earlier version of the manuscript. Their comments helped to improve the quality of this paper. This work was conducted as part of the Kimberley Island Survey of the Western Australian Department of Environment and Conservation (DEC), a project jointly funded by the Commonwealth of Australia and the Western Australian Government. Thanks are also due to everybody who contributed to the successful implementation of the survey, including the traditional landowners of the Malaya, Dambimangari, and Bardi-Jawi people, the Kimberley Land Council, and staff and associates of DEC, the Australian Museum and the Western Australian Museum.

\section{REFERENCES}

ABRS (2009). Australian Faunal Directory. Australian Biological Resources Study, Canberra. Viewed 04 May 2011. http://www.environment.gov.au/biodiversity/abrs/ online-resources/fauna/afd/index.html

Adams, A. and Angas, G.F. (1864). Descriptions of new species of freshwater shells collected by Mr F.G. Waterhouse during J. McDonald Stuart's overland journey from Adelaide to the north-west coast of Australia. Proceedings of the Zoological Society of London 1863: 414-418.

Baker, H.B. (1941). Zonitid snails from Pacific Islands. Pt III \& IV. Genera other than Microcystinae. Bulletin of the Bernice P. Bishop Museum 166: 205-370.

Bavay, A. (1908). Mollusques terrestres et fluviatiles. Nova Guinea (Zoology) 5: 269-292.

Benson, W.H. (1850). Characters of new species of Helix from India, Mauritius and the Cape of Good Hope; also of a new Mauritian Tornatellina, with remarks on the habits of a Cape Succinea. Annals and Magazine of Natural History (2) 6: 251-256.

Boettger, O. (1890). Ad. Strubell's Konchylien aus Java. I. Bericht der Senckenbergischen Naturforschenden Gesellschaft in Frankfurt am Main 1890: 137-173.

Brazier, J. (1875a). Descriptions of eight species of Australian and Tasmanian land and freshwater shells. Proceedings of the Linnean Society of New South Wales 1: 17-20.

Brazier, J. (1875b). Descriptions of eleven new species of terrestrial and marine shells from north-east Australia. Proceedings of the Zoological Society of London 1874: 668-672.
Brazier, J. (1876). Descriptions of thirty-five new species of land shells from New Guinea, Australia, and islands in the Torres Straits, collected during the Chevert Expedition. Proceedings of the Linnean Society of New South Wales $\mathbf{1}$ : 98-113.

Brazier, J. (1880). List of the land shells found on Thursday Island, with descriptions of the new species. Proceedings of the Linnean Society of New South Wales 4: 392-396.

Brown, D.S. (2001). Freshwater snails of the genus Gyraulus (Planorbidae) in Australia: taxa of the mainland. Molluscan Research 21: 17-107.

Burch, J.B. (1977). A new freshwater snail (Basommatophora: Planorbidae) form Australia, Plesiophysa (Bayardella) johni. Malacological Review 10: 79-80.

Cox, J.C. (1868). A monograph of Australian land shells. Maddock, Sydney. 111 pp.

Deshayes, G.P. (1830). Mollusques et Zoophytes. In: GuérinMéneville, F.E. (ed.), Magasin de Zoologie, journal destiné à établir une correspondance entre les zoologists de tous les pays, et à leur faciliter les moyens de publierles espèces nouvelles ou peu conneus qu'ils possedent. 2me section. Arthus Bertrand, Paris.

Fulton, H.C. (1915). Molluscan notes. Proceedings of the Malacological Society of London 11: 236-241.

Gibson, L.A. and McKenzie, N.L. (2012). A biodiversity survey of selected Kimberley islands: background and implementation. Records of the Western Australian Museum 81: $1-14$.

Hedley, C. (1888). A list of the land shells recorded from Queensland. Proceedings of the Royal Society of Queensland 5: 45-70.

Hedley, C. (1897). Descriptions of new land shells. Records of the Australian Museum 3: 44-48.

Hedley, C. (1901). Studies on Australian Mollusca. Part III. Proceedings of the Linnean Society of New South Wales 25: 721-732.

Hedley, C. (1902). Studies on Australian Mollusca. Part VI. Proceedings of the Linnean Society of New South Wales 27: 7-29.

Hedley, C. and Musson, C.T. (1892). On a collection of land and fresh water shells from Queensland. Proceedings of the Linnean Society of New South Wales (2) 6: 551-564.

Hubendick, B. (1951). Recent Lymnaeidae, their variation, morphology, taxonomy, nomenclature and distribution Kongliga Svenska Vetenskaps Academiens Nya Handlingar.

Hyman, I. T. and Ponder, W. (2010). A morphological phylogenetic analysis and generic revision of Australian Helicarionidae (Gastropoda: Pulmonata: Stylommatophora), and an assessment of the relationships of the family. Zootaxa 2462: 1-148.

Iredale, T. (1930). Notes on some desert snails. Victorian Naturalist 42: 118-120.

Iredale, T. (1933). Systematic notes on Australian land shells. Records of the Australian Museum, Sydney 19: 37-59.

Iredale, T. (1937). A basic list of the land Mollusca of Australia. Australian Zoologist 8: 287-333.

Iredale, T. (1939). A review of the land Mollusca of Western Australia. Records of the Western Australian Museum 2: $1-88$.

Iredale, T. (1940). Guide to the land shells of New South Wales. Australian Naturalist 10: 227-236. 
Iredale, T. (1941). A basic list of the land Mollusca of Papua. Australian Zoologist 10: 51-94.

Iredale, T. (1943). A basic list of the freshwater Mollusca of Australia. Australian Zoologist 10: 188-230.

Köhler, F. (2010a). Three new species and two new genera of land snails from the Bonaparte Archipelago in the Kimberley, Western Australia (Pulmonata, Camaenidae). Molluscan Research 30: 1-16.

Köhler, F. (2010b). Uncovering local endemism in the Kimberley, Western Australia: description of new species of the genus Amplirhagada Iredale, 1933 (Pulmonata, Camaenidae). Records of the Australian Museum 62: 217-284.

Köhler, F. (2011a). Australocosmica, a new genus of land snails from the Kimberley, Western Australia (Eupulmonata, Camaenidae). Malacologia 53: 199-216.

Köhler, F. (2011b). The camaenid species of the Kimberley Islands, Western Australia (Stylommatophora: Helicoidea). Malacologia 54: 203-406.

McKenzie, N.L., Johnston, R.B. and Kendrick, P.G. (eds) (1991). Kimberley rainforests of Australia. Surrey Beatty and Sons and Department of Conservation and Land Management Western Australia, Canberra, 490 pp.

McKenzie, N.L. (1991). An ecological survey of tropical rainforests in Western Australia: background and methods. In: McKenzie, N.L., Johnston, R.B. and Kendrick, P.G. (eds), Kimberley rainforests of Australia: 1-26. Surrey Beatty and Sons and Department of Conservation and Land Management Western Australia, Canberra.

Merrifield, H.E., Slack-Smith, S.M., and Wilson, B.R. (1977). Report on the mollusc fauna of the Drysdale River National Park North Kimberley, Western Australia. In: Kabay E.D. and Burbidge A.A. (eds.), A Biological survey of the Drysdale River National Park North Kimberley, Western Australia in August 1975. Western Australian Wildlife Research Bulletin 6: 110-120.

Moellendorff, O.F. von (1888). Von den Philippinen. Nachrichtsblatt der Deutschen Malakozoologischen Gesellschaft 20: 65-90.

Moellendorff, O.F. von (1890). Die LandschneckenFauna der Insel Cebu. Bericht der Senckenbergischen Naturforschenden Gesellschaft in Frankfurt am Main 1890: 189-292.

Montrouzier, R.P. (1859). Description d'espèces novelles (1). Journal de Conchyliologie 7: 286-289.

Mousson, A. (1865). Coquilles terrestres et fluviatiles de quelques Îles de l'Océan Pacifique, recueillies par M. le Dr E. Graeffe. Journal de Conchyliologie 13: 164-209.

Pfeiffer, L. (1846). Descriptions of thirty new species of Helicea, belonging to the collection of H. Cuming, Esq. Proceedings of the Zoological Society of London 1846: 28-34.

Pilsbry, H.A. (1900). Note on the Australian Pupidae. Proceedings of the Academy of Natural Sciences of Philadelphia 1900: 426-430.

Pilsbry, H.A. (1906). Achatinidae: Stenogyrinae and Coeliaxinae. In: Pilsbry, H.A. (ed.), Manual of Conchology, structural and systematic, with illustrations of the species. Second series: Pulmonata Volume 18. Conchological Department, Academy of Natural Sciences, Philadelphia.
$357 \mathrm{pp}$.

Pilsbry, H.A. (1916-1918). Pupillidae (Gastrocoptinae). In: Pilsbry, H.A. (ed.), Manual of Conchology, structural and systematic, with illustrations of the species. Second series: Pulmonata Volume 24. Conchological Department, Academy of Natural Sciences, Philadelphia. 333 pp.

Pilsbry, H.A. (1920-1921). Pupillidae (Vertigininae, Pupillinae). In: Pilsbry, H.A. (ed.), Manual of Conchology, structural and systematic, with illustrations of the species. Second series: Pulmonata Volume 26. Conchological Department, Academy of Natural Sciences, Philadelphia. 254 pp.

Pokryszko, B.M. (1996). The Gastrocoptinae of Australia (Gastropoda: Pulmonata: Pupilloidea): systematics, distribution and origin. Invertebrate Taxonomy 10: 10851150.

Preston, H.B. (1906). Description of a new species of Limnea from north-west Australia. Proceedings of the Malacological Society of London 7: 36.

Preston, H.B. (1913). New minute terrestrial and aquatic Mollusca from the Dutch East Indian Island of BeilanBeilan, with descriptions of four new genera and subgenera. Annals and Magazine of Natural History (8) 2: 432-439.

Puslednik, L., Ponder, W.F., Dowton, M. and Davis, A.R. (2009). Examining the phylogeny of the Australasian Lymnaeidae (Heterobranchia: Pulmonata: Gastropoda) using mitochondrial, nuclear and morphological markers. Molecular Phylogenetics and Evolution 52: 643-659.

Quadras, J.F. and Moellendorff, O.F. von (1894). Diagnoses specierum novarum ex insulis Philippinis. Nachrichtsblatt der Deutschen Malakozoologischen Gesellschaft 26: 113-130.

Shuttleworth, R.J. (1852). Diagnosen neuer Mollusken. Mitteilungen der Naturforschenden Gesellschaft in Bern 1852: 193-208.

Slack-Smith, S. (1993). The non-marine molluscs of the Cape Range Peninsula, Western Australia. In: Humphreys, W.F. (ed.), The Biogeography of Cape Range, Western Australia. Records of the Western Australian Museum 45: 87-108.

Smith, B.J. (1992). Non-marine Mollusca. In: Houston, W.W.K. (ed.), Zoological Catalogue of Australia Volume 8. AGPS, Canberra. 405 pp.

Smith, E.A. (1894). On the land-shells of Western Australia. Proceedings of the Malacological Society of London 1: 84-99.

Smith, B.J. and Kershaw, R.C. (1979). Field guide to the nonmarine molluscs of south eastern Australia. Australian National University Press, Canberra. 285 pp.

Solem, A. (1960). Non-marine Mollusca from the Florida Islands, Solomon Islands. Journal of the Malacological Society of Australasia 4: 39-56.

Solem, A. (1964). Amimopina, an Australian enid land snail. Veliger 6: 115-120.

Solem, A. (1973). Convergence in pulmonate radulae. Veliger 15: $165-171$.

Solem, A. (1982). Small land snails from Northern Australia, II: Species of Westracystis Iredale, 1939 (Mollusca: Pulmonata, Helicarionidae). Journal of the Malacological Society of Australia 5: 175-193.

Solem, A. (1983). Endodontoid land snails from Pacific Islands (Mollusca: Pulmonata: Sigmurethra). Part II. Families 
Punctidae and Charopidae, Zoogeography. Field Museum, Chicago. 336 pp.

Solem, A. (1984). Small land snails from Northern Australia. III. Species of Helicodiscidae and Charopidae. Journal of the Malacological Society of Australia 6: 155-179.

Solem, A. (1986). Pupilloid land snails from the south and mid-west coasts of Australia. Journal of the Malacological Society of Australia 7: 95-124.

Solem, A. (1988). Non-camaenid land snails of the Kimberley and Northern Territory, Australia. 1. Systematics, affinities and ranges. Invertebrate Taxonomy 2: 455-604.

Solem, A. (1991a). Land snails of Kimberley rainforest patches and biogeography of all Kimberley land snails. In: McKenzie, N.L., Johnston, R.B. and Kendrick, P.G. (eds), Kimberley rainforests of Australia: 145-246. Surrey Beatty and Sons and Department of Conservation and Land Management Western Australia, Canberra.

Solem, A. (1991b). Distribution and diversity patterns of Australian pupilloid land snails (Mollusca: Pulmonata: Pupillidae, s.1.). Veliger 34: 233-252.

Solem, A. and McKenzie, N.L. (1991). The composition of land snail assemblages in Kimberley rainforests. In: McKenzie, N.L., Johnston, R.B. and Kendrick, P.G. (eds), Kimberley rainforests of Australia: 247-263. Surrey Beatty and Sons and Department of Conservation and Land Management Western Australia, Canberra.

Stanisic, J., Shea, M., Potter, D. and Griffiths, O. (2010). Australian land snails Volume 1. A field guide to eastern Australian species. Bioculture Press, Riviere des Anguilles, Mauritius, 590 pp.

Tate, R. (1894). Brief diagnoses of Mollusca from Central Australia. Transactions of the Royal Society of South Australia 18: 191-194.
Tate, R. (1896). Mollusca. In: Spencer, W.B. (ed.). Report on the Work of the Horn Scientific Expedition to Central Australia. Part 2 Zoology: 181-226. Mullen and Slade, London and Melbourne.

van Benthem Jutting, W.S.S. (1950). Systematic studies on the non-marine Mollusca of the Indo-Australian Archipelago. II. Critical revision of the Javanese pulmonate land-shells of the Families Helicarionidae, Pleurodontidae, Fruticicolidae and Streptaxidae. Treubia 20: 381-505.

van Benthem Jutting, W.S.S. (1952). Systematic studies on the non-marine Mollusca of the Indo-Australian Archipelago. III. Critical revision of the Javanese pulmonate land-snails of the Families Ellobiidae to Limacidae, with an appendix on Helicarionidae. Treubia 21: 291-435.

van Benthem Jutting, W.S.S. (1958). Landmollusken von Sumba. Verhandlungen der Naturforschenden Gesellschaft in Basel 69: 90-117.

van Benthem Jutting, W.S.S. (1964). Non-marine Mollusca of West New Guinea. Part 3, Pulmonata, I. Nova Guinea (Zoology) 26: 1-74.

Wagner, A.J. (1907-1911). Die Familie der Helicinidae. In: H.C. Küster (ed.), Systematisches Conchylien - Cabinet von Martini und Chemnitz, Neue Folgen. Bauer and Raspe, Nürnberg. Vol. 18, 391 pp.

Walker, J.C. (1988). Classification of Australian buliniform planorbids (Mollusca: Pulmonata). Records of the Australian Museum 40: 61-89.

Zilch, A. (1959). Euthyneura. In: Schindewolf, O.H. (ed.), Handbuch der Paläozoologie. Berlin-Zehlendorf: Bornträger Vol. 6, 834 pp.

MANUSCRIPT RECEIVED 19 AUGUST 2010; ACCEPTED 24 AUGUST 2011. 